\title{
تطوير منهج العلوم للمعاقين عقلياً فى المرحلة الابتدائية
}

\section{في ضوي متطلبات التزبية الههنية}

جماد عماد الدين وهيب

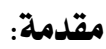

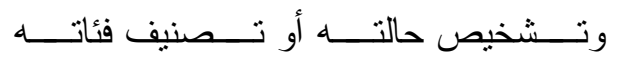
المختلفة ، بل إلي محاولة دمج هذه الفئـات

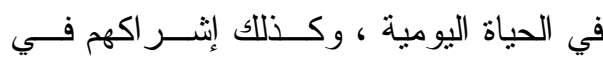
سوق العمل من أجل الاستفادة من إمكانياتهم

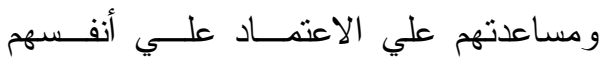
فـي تــصريف شـــؤهم حتــى يـشعروا

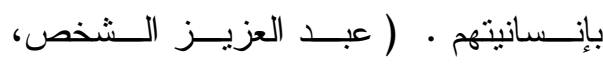
(r) 6 r... ولقد أصبح التعليم في وقتتا الـــراهن

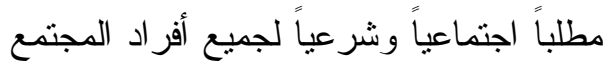

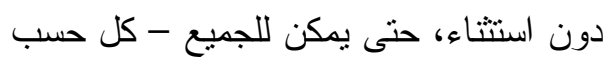

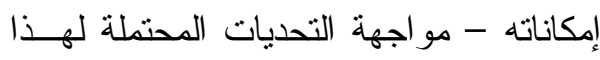

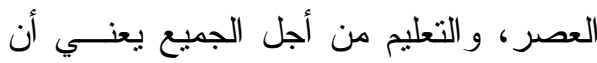

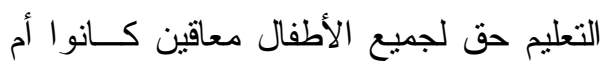
غير معــاقين، وينبخــي أن يتــوفر التعلــيم

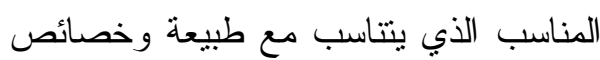

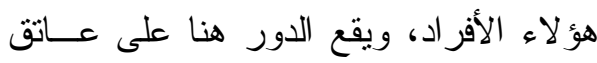
المدرسة التي تعتبر المكان الرسمي لتعلــيم

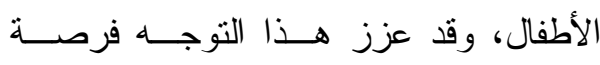

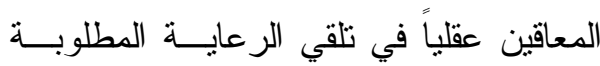
و المناسبة. (إير اهيم شــعير، إيمسـان جـاد، (V) 6. T. 0
تمنل الاعاقة العقلية بمختلف درجاتها تحديا كبير ا لكل من يتعامل مــع المــصابين بهذه الاعاقة ؛ لأن العجز و القصور يتمثنـل

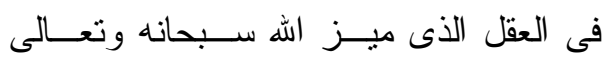
الإنسان عن سائر المخلوقات؛ لذلك فإن هـــا

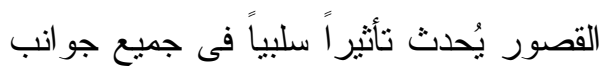

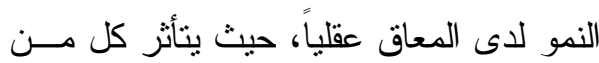

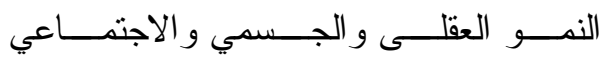

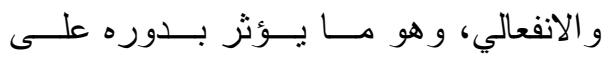

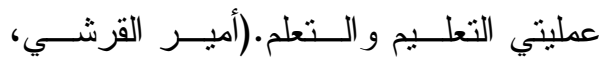
(1T) G $T \cdot 14$ ويشير عادل عبد الله (ع ...T، إلي أن الأطفال من ذوي الإعاقـــة العقليــة

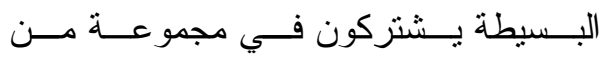

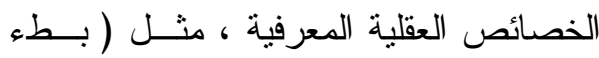
النمو العقلي - وضعف الانتباه - وقــصور الذاكرة - وقصور الإدر الك - وضعف القدرة علي التفكير - وقصور المهارات الأكاديمية - وقصور المهار ات الحركي ). لذا احتلت در اسة هـــذه الفئــة مــن

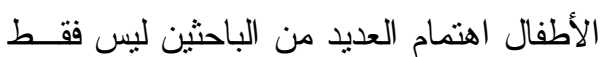
من أجل التعرف علي مسبيات الإعاقة العقلية 
طويلة الامد داخل مراكز التزبية الخاصة .، ولذا يعتمدون على غير هم طو ال حياتهم. وتمنت فئة المعاقين عقلياً القابلين للتعلم

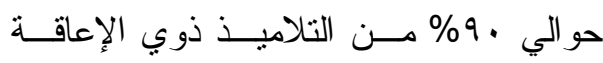
العقلية، ويتسم أفراد هذه الفئة بأنهم يتعلمون ببطء فى المدارس، وربما فى وظائفهم، و هم

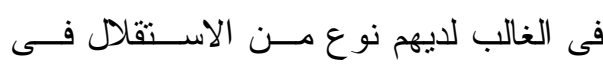
المجتمع، ومسئولون عن تدبير احتياجــاتهم

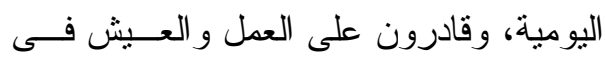

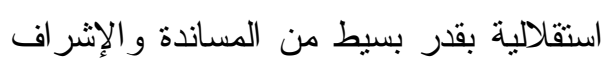
و المر اقبة.

والإعاقة الموجودة لاى هؤلاء الأفر اد

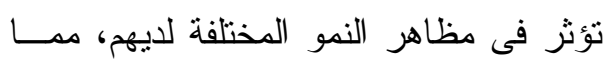
يثكل قيوداً وظيفية كبيرة وتحديات حقيقيـــة

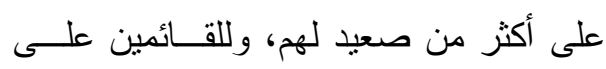

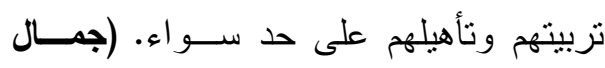

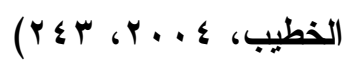

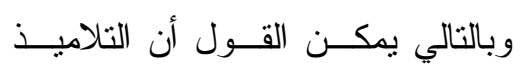

المعاقون عقلياً يمنلون مشكلة منفــردة فــي لئي تعليمهم وتعلمهم، حيث تتطلب عملية تعلــيم

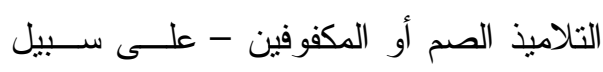
المثال - إجراء تعديلات في طرق التدريس

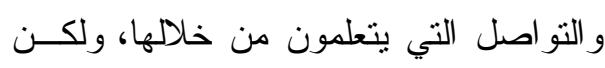

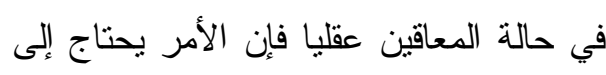
أن يقرر المتخصصون، ما الذي ينبغي علينا

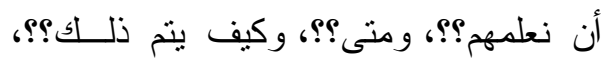
نظر التأثثر القدرة العقلية في عملية التعلم.
ويصنف المعاقون عقلياً وفقاً للتصنيف

التربوي فى ثناث فئات هى (كمال زيتـــون، $:(r, r, r, r) r$

1 - القابلون للتعلم: Educable

وتتضمن التلاميذ القادرون على تعلـــم

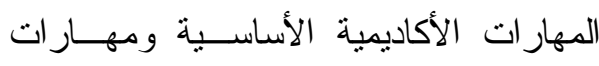

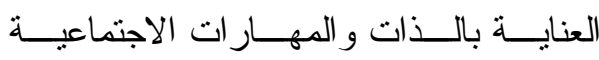

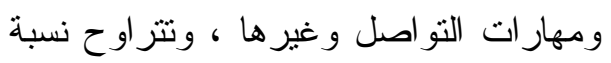

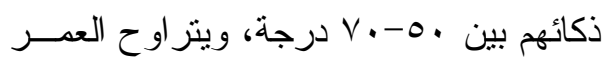

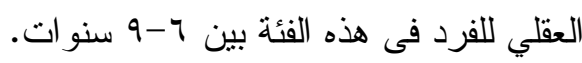

\section{r - القابلون للتدريب: Trainable}

ونتشمل مجموعة التلاميــذ القــادرون

على تعلم مهار ات وظيفية مثل العناية بالذات

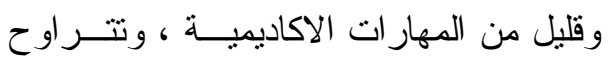

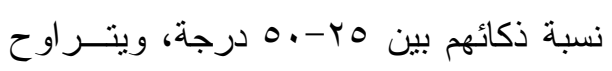

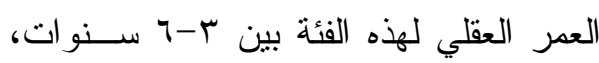
ويهدف برنامجهم التعليمي إلى التدريب على لى لهين

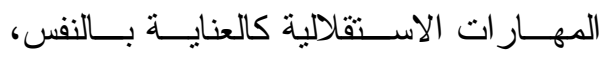

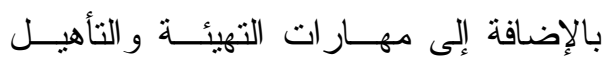
المهني. r- الاعتماديون: Custodial تتضمن هذه الفئة الأطفال الذين تقــلـ نسبة ذكائهر عن Oب درجة، و العمر العقلـي لإهي

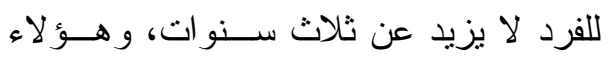
الافر اد يحتاجون الى رعاية خاصة مـستصرة 
اتاحة الفرصة للمعاق عقلياً لتطـــير

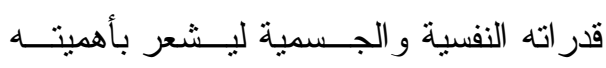

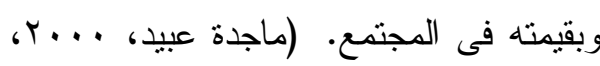

ولما كانت التربية المهنية تهتم بشكل

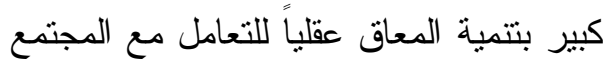

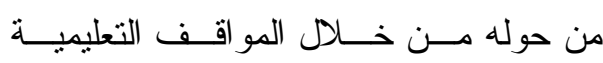
وتهيئته لنغل مهنة وفقاً لقدر اته ومنطلبــات التربية المهنية، فالموقف مهم فى تعلم العلوم

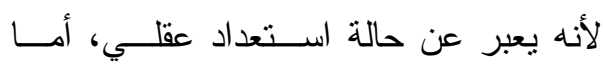

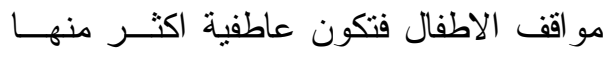
عقلية، فالمو اقف مهمة فى حياة الاطفال حيث يمكن أن يظهروا محبتهم لمادة العلوم عندما

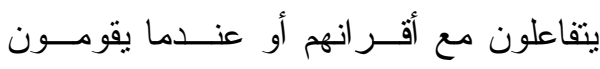
بالاستكثاف، ويمكن أن يصبح تقدير الأطفال للعلوم أكبر عندما يدركون منفعــة العلــوم و أهية العلوم فى حياتهم اليومية، ويدركون لئن

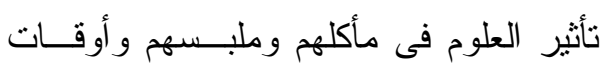

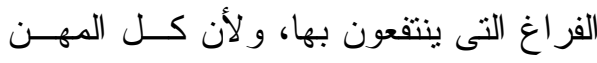

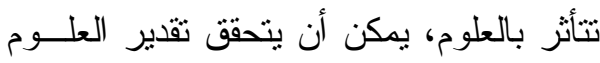

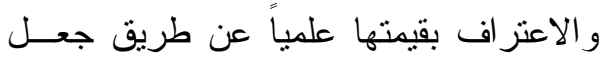

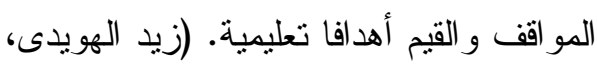

$(r \wedge, t \cdot) t$

كما أن حيــاة الانـسـان وممارســاته اليومية مرنبطة ارنباطاً وثيقاً بشكل أو بأخر

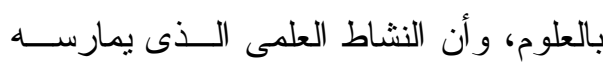

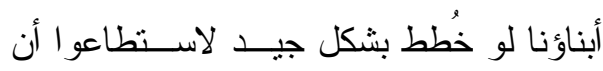

ولقد أوصت العديد مــن المــؤتمر ات

التي عقدت بهدف الاهتمام بالأطفال المعاقين

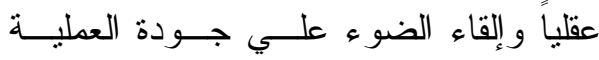

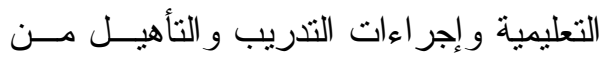

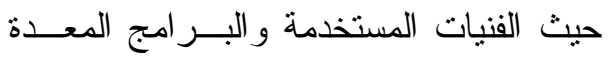
خصيصا لهذه الفئة. ويركز التأهيل المهني علــى اعـــداد المعاق عقلياً للالتحاق بعمل مناسب جنباً إلى الى الى

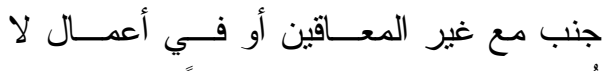
تُعرض الشخص للخطر وبعيداً عن تحمُــل فئل

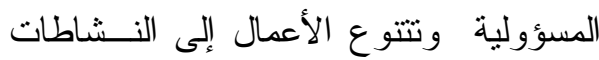

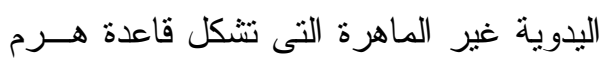

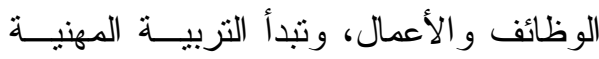
بتوجيه مهني وعدة منطلبات للتربية المهنيـــة وهى :

• تحديد فرص العمل التى يمكن أن تتوفر

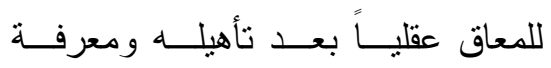

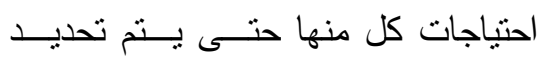

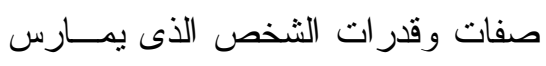

$$
\text { المهنة. }
$$

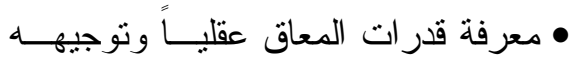
للمهنة المناسبة له. • تقديم المشورة للمعاق عقليــاً لاختيــار

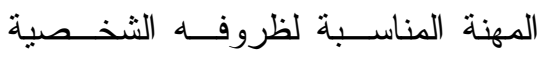

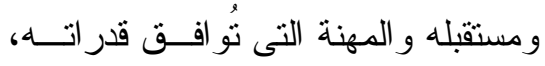

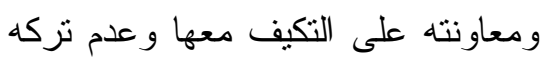
لأهو ائه وميوله الثخصية فقط. 
وتتعدد الدر اسات التى اهتمت بعمليـــة

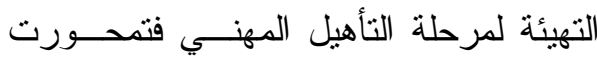

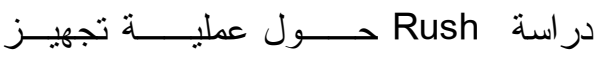

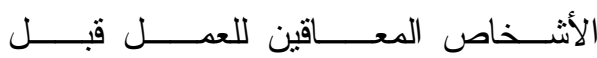

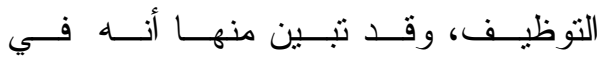

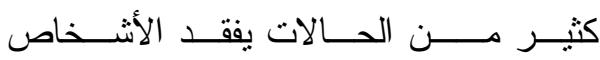
المعاقين و وظائفه و لا يسنطيعون المحافظــــة

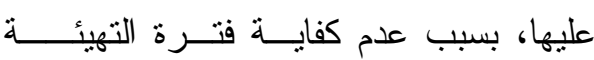

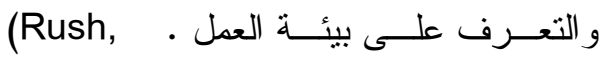

كما توصلت در اســة Millonzi, C 1985 و التى هدفت إلى وضع تصور عن

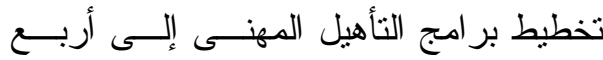
مجالات يجب أن نتنمل عليها بر امج التأهيل

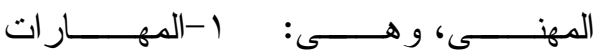

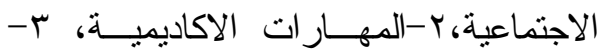

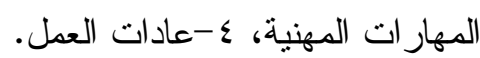

(Taylor, فى حين توصلت در اسة

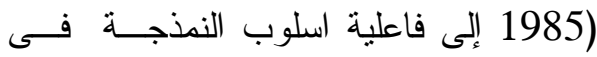
اكساب المعاقين عقلياً المهــار ات الاساســية

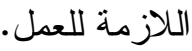

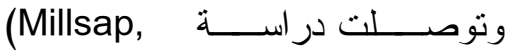
Rogger,1998)

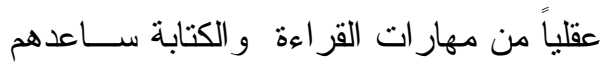
على اكتساب المهار ات المهنية.
يعايثوا متعته. (حمدى أبو الفتـوح وســعيد

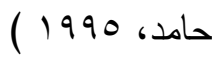
ويؤكد (Fabian, E,2007 ) من خــله تقييمه لبرامج التأهيل المهنـي للمعــاقين عقلياً عدة توصيات منها :

• التوسع في مجالات التـدريب لتـشمل مجالات أوسع ومهن أصعب.

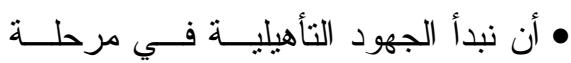
الطفولة المبكرة .

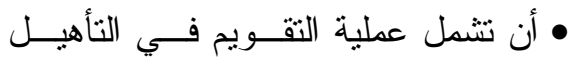
المهني الجو انب العقلية و البدنية و السلوك • التكيفي • بناء عملية التقويم علــى أدوات مقنــــة علاوة على أن يتصف بالاستمر ارية. ونتشل منطلبات المعاقين عقلياً أيضاً: خدمات مهنية وارشادية وتربوية و اجتماعية

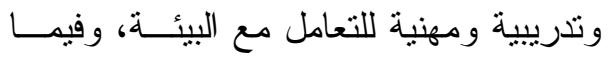
يتعلق بالحاجات المهنية فإنها تتمنل فى نهيئة لئه

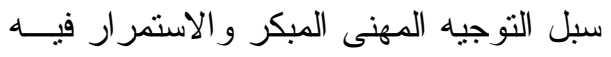
لحين الانتهاء من العملية التأهيلية و إصـــدار

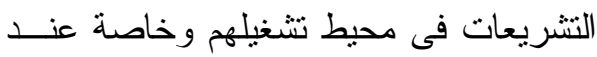

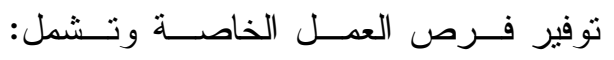
الخدمات الوقائية وخدمات الحصر و التسجيل

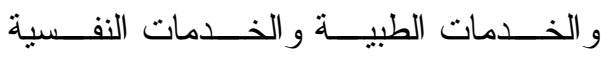

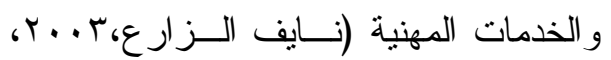
. 100 
الحاجة لتتمية تلـــــ المهــار ات وخــصوصـاً

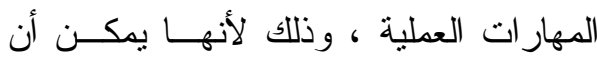

تسهم في تقليل نواحي القصور لديهم، وتلبية

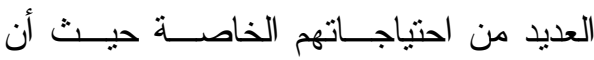

الهدف الاسمى و الرئيس من تعليم المعـاقين

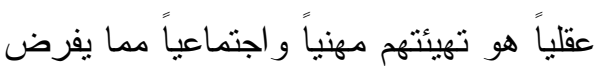

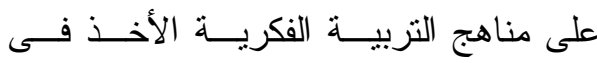

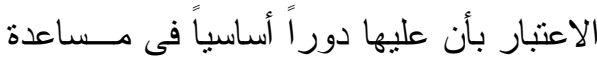

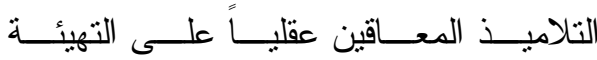
و الاستعداد لنتقى بر امج التربية المهنية، وذلك من خلال الاهتمام بتتمية الجوانــب العمليـــة

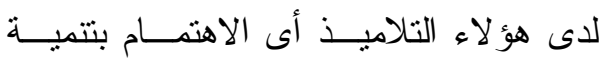

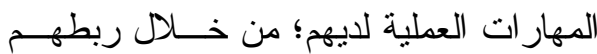
بالمجتمع في ضو ء متطلبات التربية المهنيـــة ومن خلالها يتم تتمية الاتجاه نحــو العـــل

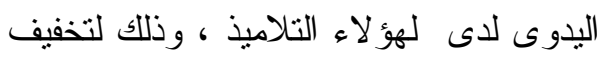

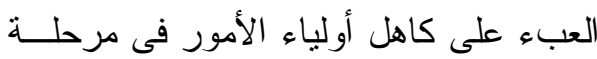

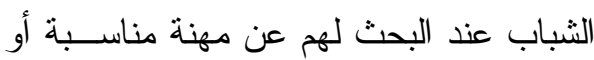
عمل مناسب لطبيعة الاعاقة يكسب منه يومه ويميل إليه، ولذا يركز البحث الحالى علـى أهمية اتخاذ البيئة مــصدر اً للــتعلم، وقيــام هؤلاء التاميذ بممارسة الأنشطة التعليميــة

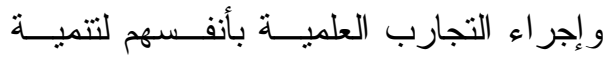

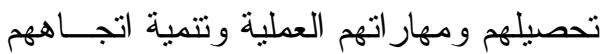

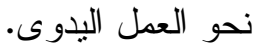

ومن الدر اسات التى اهتمــت بتتميــة المهار ات العملية للمعــقين در اســـة إيمــان
يتضح من خلال مـــا ســبق أهميــة

وضرورة تمكين المعاق عقليا من اكتـساب

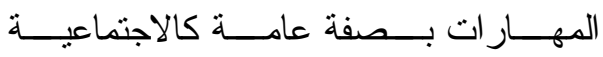

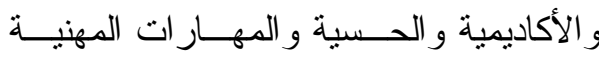
بصفة خاصة وعادات العمل وتهيئة المعـاق ولات ولان

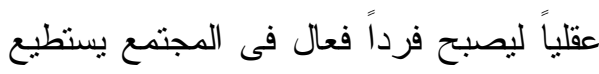
تلبية منطلباته واحتباجاته بذاته دون الاعتماد

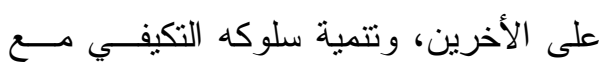
أفر اد المجتمع من حوله.

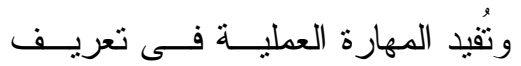
المتعلم أكثر على عالم المهن التى يتخصص لهص بها الأفراد بالمستقبل مما يجعله أكثر وعيـاً لمتطلبات تللك المهن مـن حيــث القــدرات العقلية و الجسمية ، يضاف إلى ذلـــــ أن أداء

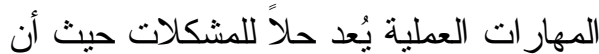
أداء المهارة يكون ضمن أداء مهمة حياتيــة متكاملة، ويؤدى التعامل مع المهمات التـى لتصن تتضمن مشكلات حياتية إلى زيادة القدرات التفكيرية لدى المتعلمين. (سوسن بدرخان، (70 6 Y . . T

وتعتمد المهار ات العملية على طبيعـة منهج العلوم الذي يشمل كافــة المعلومــات لــات

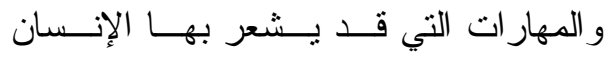
ويحسها أو يشاهدها بصريا أو يدركها سمعيا

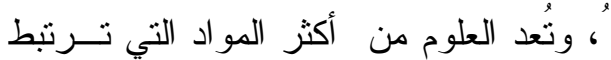

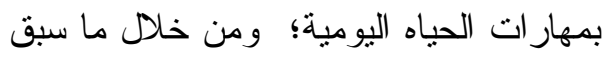

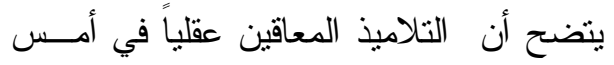


كمـا أجـرى Scruggs, T. \&

Mastropieri, M.: 1992) لمناهج العلوم وبر امج العلوم الموجهة لذوي

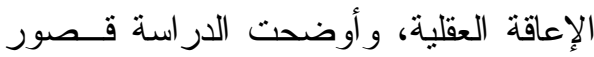

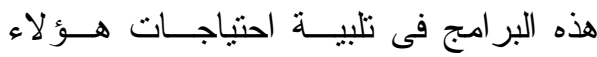
التلاميذ فيما يتعلق بالمهار ات الحياتية العملية

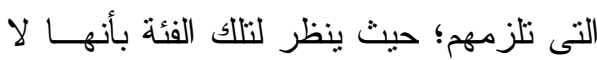

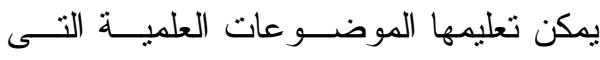

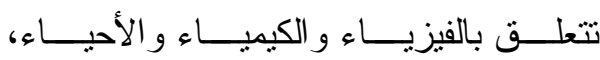
و المهار ات المرتبطة بها، و أوضحت الدر اسة ولة أنه يمكن من خلال مناهج العلــوم إكــــابهر

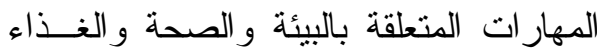

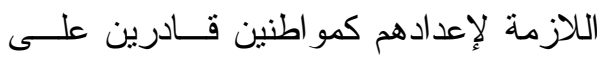
التفاعل مع من حولهم. وتؤكد الباحثة على أهمية الاهتمــام

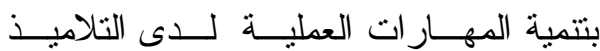

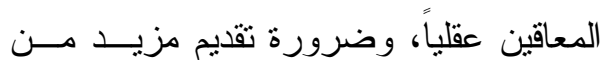

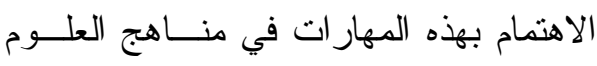

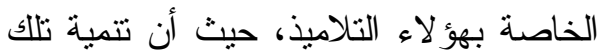

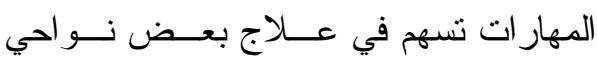
القصور و المشكلات التى يعاني منها هؤلاء التلاميذ، وينبغي أن يُقدم للتلاميــذ المعــاقين

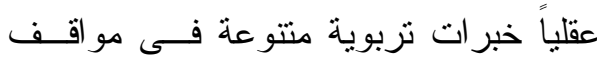
الحياة اليومية، وبصورة متر ابطة ومتكاملـــة تساعد الطفل المعاق عقلياً علــى الاســتجابة

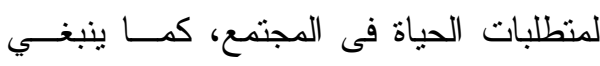

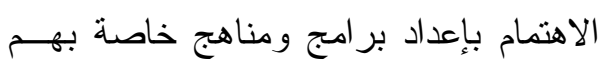

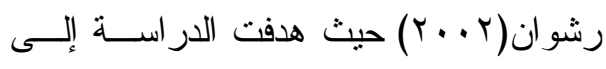

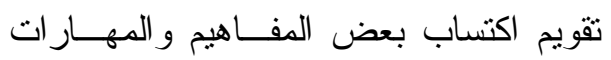
العملية فى تتفيذ الملابـس لــدى نلميـــات

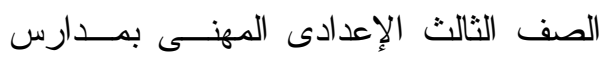

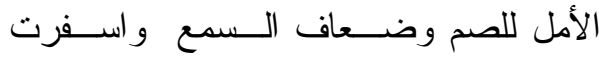

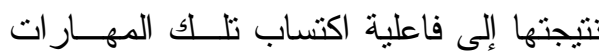
فى تتفيذ الملابس بصورة سليمة. و هدفت دراســة ســميرة حجـازى (Y..人) إلى التعرف على المهارات العملية الو اجب نو افرها لـــــي الطالبـــات المعاقـــات سمعيا اللاتى يدرسن مادة التدريبات المهنيــة

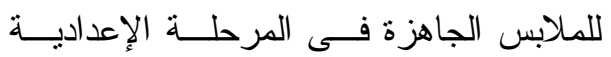

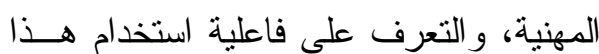
البرنامج فى تتمية بعض المهار ات العمليــة

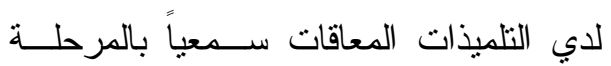
الإعدادية المهنية.

وتعد المناهج التعليمية محوراً هامـاً من محاور العملية التعليمية بل تعتبر العمود

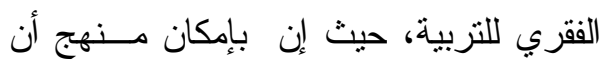

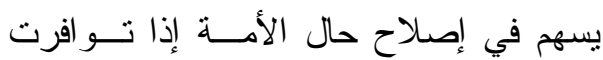

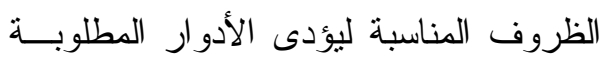

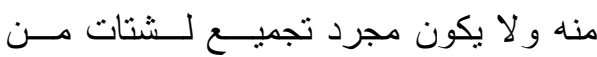

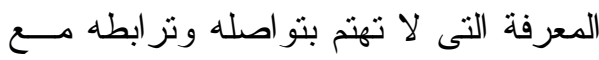

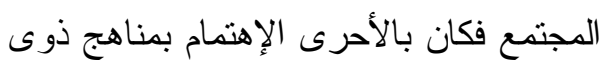

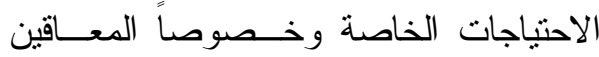

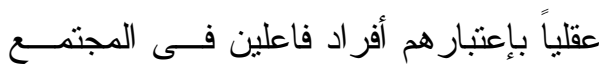
وفى البيئة النى يعيشون بها. 
التى ينبغى أن تسعى إليها العملية الثربويـــة فى المدارس الخاصة بالمعاقين عقلياً.

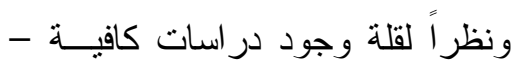

على حد علم الباحثة - وخاصة فـي الــدول العربية تتتاول إعداد مناهج ــوبر امج لتتمية

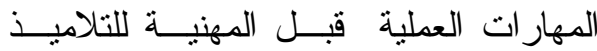
المعاقين عقلياً القابلين للتعلم، فــإن الدراســـة

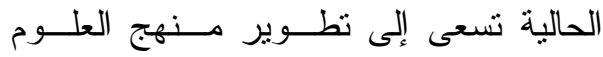

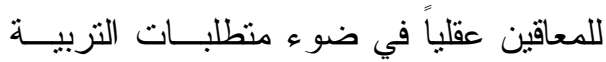
المهنية ودوره في تتمية المهــار ات العمليــة و الاتجاه نحو العمل اليدوى.

الاحساس بمشكلة البحث النئ

جاء الاحساس بالمشكلة مـن خــلال

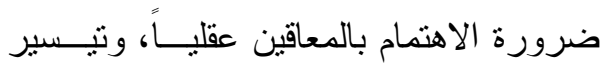

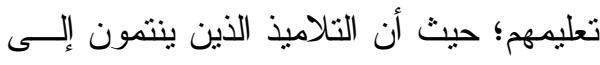
مجموعات غير متجانسسة مــن الاعاقـات

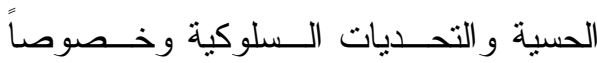

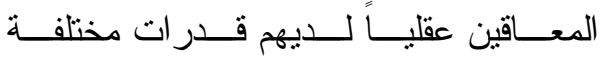

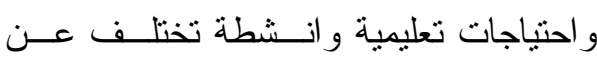
العاديين وبالتالى يو اجهون تحديات فى التعلم

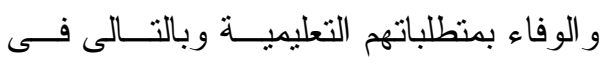

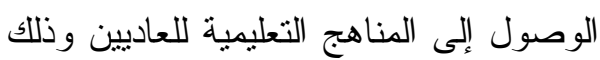

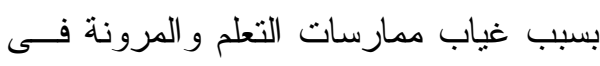
Edyburn, 2010,P 33,Shurr \& التعليم

(Bouck, 2013, 76)

وبالنظر إلى و اقع مناهج تعليم العلوم للتلاميذ المعاقين عقلياً بالمرحلة الابتدائية وما
تلبي احتياجاتهم وتناعد في تتمية المهــار ات

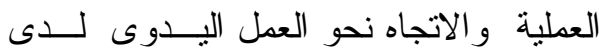

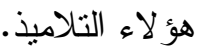

مما سبق عرضــهـ فــى الدراســات

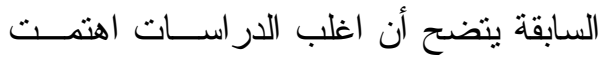
بتتمية المعاق عقليا القدر الكافى من التتميـــة

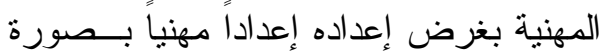
متكاملة ليسنطيع التكيف مع ظروف العدـلـل وظروف المجتمع فيما بعد، وقــــ أوصـــت فئس

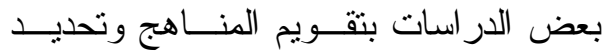

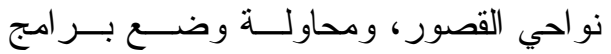
تساعد على معالجة نواحي القصور من أجل

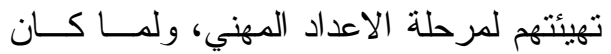
الهدف الرئيس لتعلم المعاق عقلياً هو الإعداد

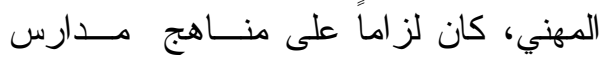
التزبية الفكرية بصفة عامة ومناهج العلــوم بصفة خاصة أن نر اعى منطلبات و احتباجات

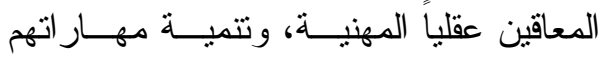
الثخصية وبصفة خاصة المهار ات العمليــة لما لها من فاعلية فى تأهبلهم للحياة المهنيـــة فيما بعد. وبالنظر إلى هذه الأهداف يتـضح أن

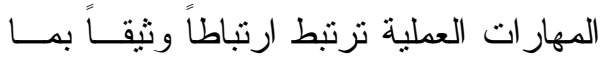
يجب أن تسعى المناهج الخاصــة بالمعـاقين

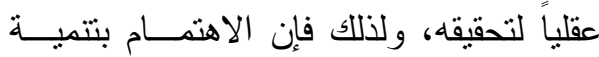
المهارات العملية يعد أحد الأهداف الأساسية 


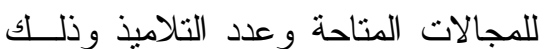

من وجهة نظر معلمى التزبية المهنية. r.مقررات العلــوم لا تتمــى المهــارات

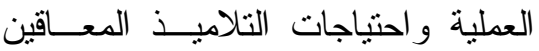
عقلياً المختلفة بدرجة كافية، وذللك مسن ولن

$$
\text { وجهة نظر معلمى العلوم. }
$$

ع ـ هنـــاك اتفــاق مــن جانــب المعلمـين

و الموجهين بمدارس التربية الفكرية على هلى

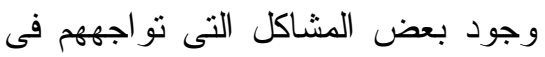
مناهج العلوم بالمرحلة الابتدائية.

ه.مقرر ات العلوم لا تفى بمنطلبات التربية المهنية للمعاقين عقلياً بالمرحلة الابتدائية و لا تتاسب خصائــصهم و احتياجــاتهم التعليمية؛ لذا هدف البحث الحالى إلــى ولـى تطوير منهج العلوم للمعاقين عقلياً فـى لهـى

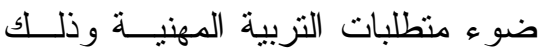
بهدف تتمية التحصيل و المهار ات العملية لديهر و الاتجاه نحو العمل اليدوى لديهم.

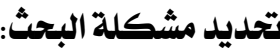

إن الصعوبات التى تقرضها الإعاقـــة العقلية تعوق التلاميذ المعاقين عقليــاً عــن الاعن تتمية المهار ات العلمية التى تتطلبها عمليـــة تكيفهم مع ظروف إعاقتهم، ومع منطلبــات

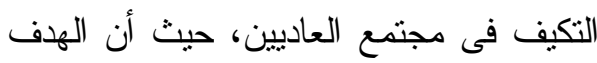
الرئيسى من تعلم المعاقين عقليا هو تـــأهيلهم

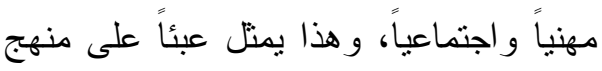

بها من سلبيات وصعوبات تحد مــن تلبيـــة

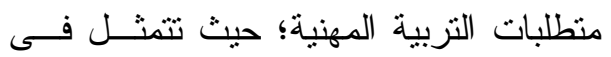
ضعف ارتباطها بالمتطلبات المهنية للمعاقين عقلياً ويدعم ذلك ما يلى: أولاً: الزيارات الميدانية :

الملاحظـــة الثخــصية مسـن خـلال

الزيار ات الميدانية لبعض مــــارس التربيـــة

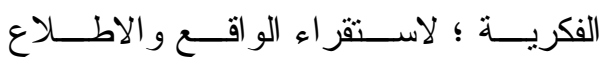
ومر اجعة مناهج العلوم المقررة على التلاميذ لاهئ

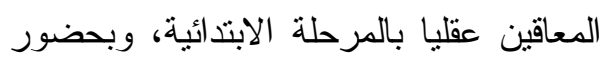
بعض حصص تدريس العلـــوم و التــدريبات المهنية لهم ومن و اقع تعامل الباحثة مع تللك الفئة و التطبيق على أولئك التلاميذ فى مرحلة

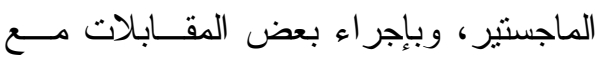

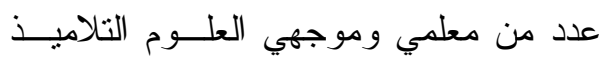

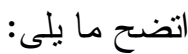

ا.مناهج العلوم المقدمة للمعـاقين عقليــا بالمرحلة الابتدائية لا تفــي بمنطلبــات

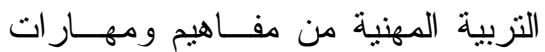
و التىى سوف تتضـح بإجر اءات الدر اســـة الاسنطلاعية و البحث الحالى.

ب.المجالات المهنيــة الخاصـــة بالتلاميــذ

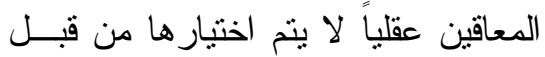

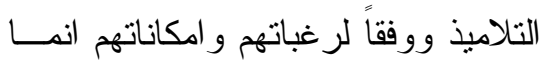
يتم اختيار ها بصورة عـشـو ائية وطبقـاً 
ع. مـــا موضـــوعات العلـــوم المرتبطـــة

بمتطلبات التزبية المهنية للمعاقين عقلياً

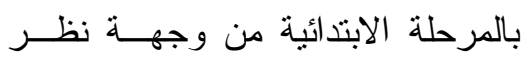

$$
\text { المعلمين و الخبر اء؟ الابكائ من }
$$

ه. ما التصور المقترح للـــنهج المطــور

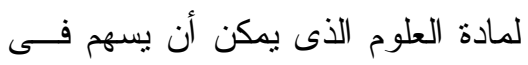

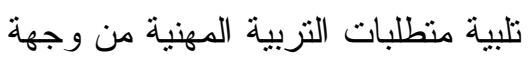

$$
\text { نظر المعلمين و الخبر اء؟ }
$$

7. ما صـــورة أدوات الدر اســـة الكيفيــة

المتمثلة (الاختبار التحصيلى - بطاقــة

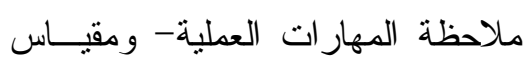

الاتجاه نحو العمل اليدوى ؟

ب- اسئلة البحث الكمية:

تم تحديد اسئلة البحث الكميــة التـى

تتعلق بدلالات الفروق بين منوسطات رتــب

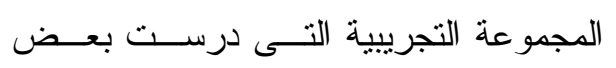

وحدات المنهج المقترح و المجموعة الضابطة

التى درست وحدات المقرر المعتاد، ومن ثم وحثن

حساب قيم الفاعلية المطلوبة، و هذه الاســئلة

ا ـ ما فاعلية التصور المقترح فى تتميــة

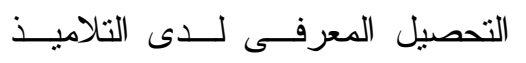

المعاقين عقلياً بالمرحلة الابتدائية ؟

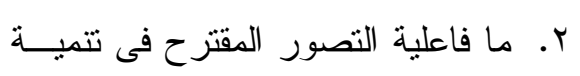

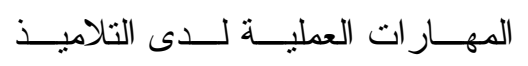

المعاقين عقلياً بالمرحلة الابتدائية ؟
العلوم بمدارس التربية الفكرية؛ لكي تكــون

قادرة على الوفاء بمنطلبات تكيف المعـاقين

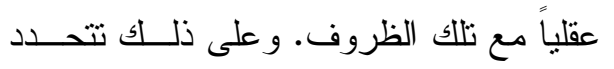

مشكلة الدراسة فى السؤال الرئيس التالي:

ما فاعلية منهج العلوم المطور فى ضــوء

متطلبات التربية المهنية فى تتمية التحصيل

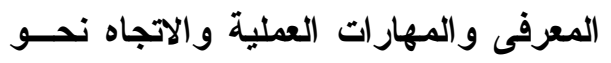

العمل اليدوى لدى التلاميذ المعاقين عقلياً ؟

وللإجابة عن سؤال الدراسة الرئيس طرحت

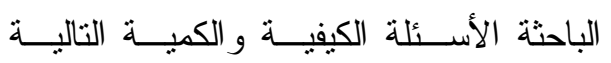
كما بلى :

\section{أ-اسئلة البحث الكيفية:}

تم تحديد أسئلة الاراسة الكيفية فيما يلى:

ا ـ ما متطلبات التزبية المهنيــة اللازمـــة

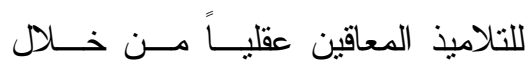

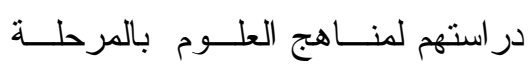

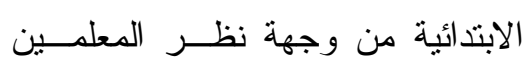

$$
\text { و الخبر اء ؟ الأبل هن }
$$

r. ما مدى تو افر متطلبات التربية المهنية

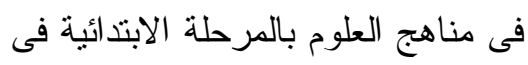

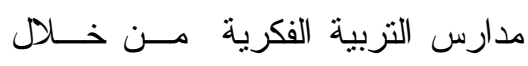

$$
\text { تحليل محتوى المنهج الحالى؟ }
$$

r. ما مدى تو افر منطلبات التربية المهنية

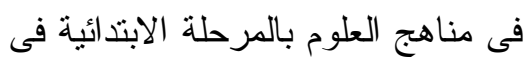

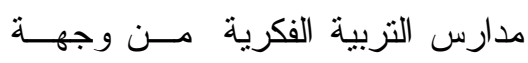
نظر المعلمين و الخبر اء؟ مدربه 
تلاميـــذ المجموعـــة التجريبيـــة فــي

التطبيقين (القبلي و البعـدي) لبطاقـــة الملاحظة لصالح التطبيق البعدي".

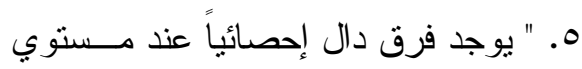

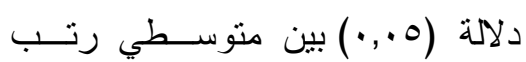

درجات تلاميذ المجموعتين (التجريبية و الضابطة) في التطبيق البعدي لمقياس

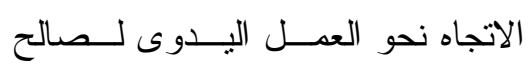
المجمو عة التجريبية ".

7. " يوجد فرق دال إحصائياً عند مستوي

(0. . . ) بين متوسطي رتب درجات درات

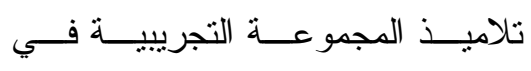

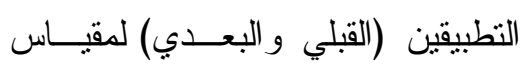

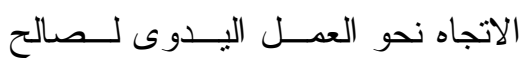

التطبيق البعدي ".

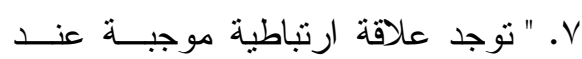

مستوي (0.، .) بين تحصيل تلاميـذ

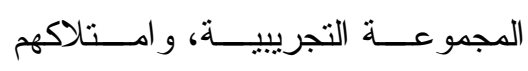

للمهار ات العملية، واتجاههم نحو العمل

$$
\text { البدوى ". }
$$

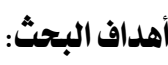

تتحدد أهداف البحث فيما يلي:

1-تعرف فعالية منهج العلوم المقترح فـى

ضوء منطلبات التربية المهنية فى تتمية

التحصيل لدى التلاميذ المعاقين عقليـاً

بالمرحلة الابتدائية. r. ما فاعلية التصور المقترح فى تتميـــة

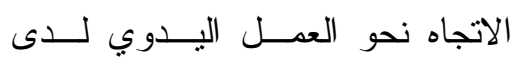

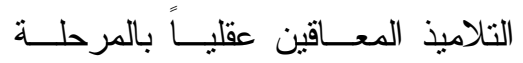

الابتدائية ؟

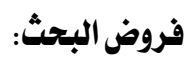

أمكن صياغة فروض البحث علــى النحــــ النتالي:

1. " توجد فرق ذو دلالة إحـصائية عنـــ

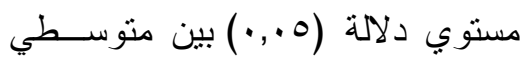

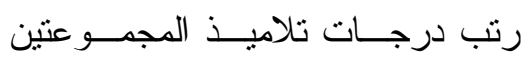

(التجرييية و الضابطة) فــي التطبيــق رئق

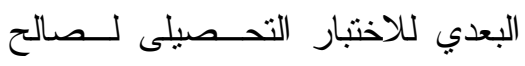

المجموعة التجريبية ".

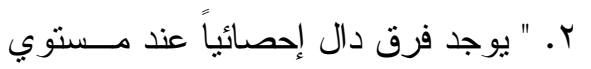

(0., · ) بين متوسطي رتب درجات دات

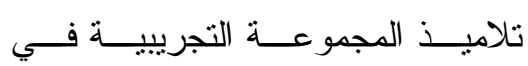

التطبيقين (القبلي و البعدي) للاختبـــار

التحصيلى لصالح التطبيق البعدي ".

r. " يوجد فرق دال إحصائياً عند مـستوي لئي

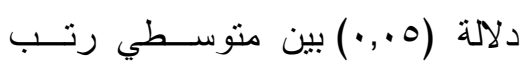

درجات تلاميذ المجموعتين (التجريبية

و الضابطة) في التطبيق البعدي لبطاقة

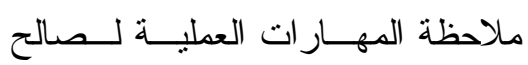

المجموعة التجريبية ".

ع. " يوجد فرق دال إحصائياً عند مستوي

(0., · ) بين متوسطي رتب درجات درائ 
ب. التزم البحث الكمي بالحدود التالية العينة :اقتصرت عينة البحث علـى

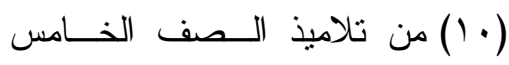
الابتدائي بمدارس التزبيــة الفكريــــة

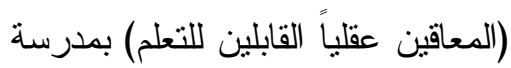
التزبية الفكرية بالسنبلاوين كمجموعة

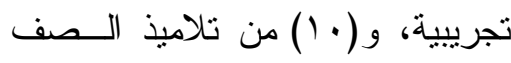

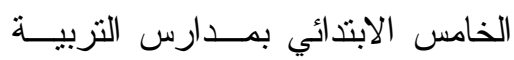
الفكرية (المعاقين عقلياً القابلين للتعلم)

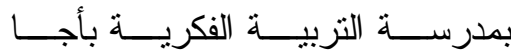
كمجمو عة ضابطة. المجال الزمنــى: الفــصل الدراسـي

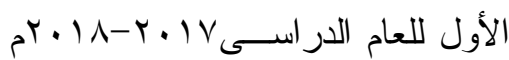

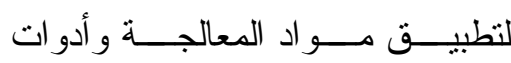
الدر اسة الكمية.

المحتوى :وحدة مدمجة من وحسدات

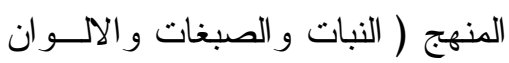
و الغذاء ) بمقرر العلوم المقترح القائم على منطلبات التزبية المهنية للمعاقين عقليا بالمرحلة الابتدائية.

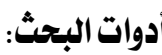

1- استمارة المقابلة الثخــصية (إعــداد

الباحثة)

r- استبانة لتحديـــــ منطلبــات التزبيــة

$$
\text { المهنية. (إعداد الباحثة) }
$$

ץ-تعرف فعالية منهج العلوم المقترح فـى

ضوء متطلبات التربية المهنية فى نتمية المهارات العملية لدى التلاميذ المعاقين عقلياً بالمرحلة الابتدائية. r-تعرف فعالية منهج العلوم المقترح فـى ضو ء منطلبات التربية المهنية فى تتمية الاتجاه نحو العمل اليدوى لدى التلاميذ المعاقين عقلياً بالمرحلة الابتدائية.

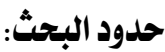

أ. التزم البحث الكيفي بالحدود التالية: العينــة ( (0) مــن معلمــى العلـــوم ومعلمى المجالات المهنية و الموجهين على مستوى الدقهلية بمدارس التزبية

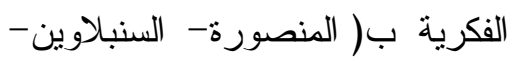
سنفا- ميت غمر - اجا- منية النصر ) و عدد من المحكمين تخصص المناهج وطرق الترريس و التزبية الخاصة .

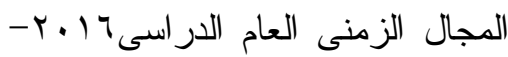

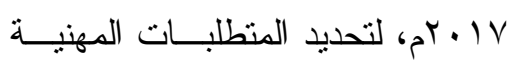

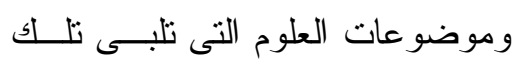

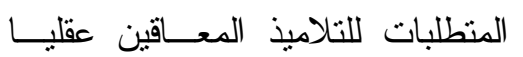
بالمرحلة الابتدائية. الاجر اءات: تحديد منطلبات التزبيــة

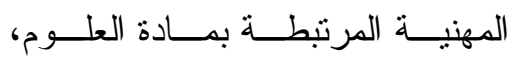
وصورة من التصور المقترح للمنهج، وبناء أدوات الدر اسة الكمية وضبطها. 


$$
\begin{aligned}
& \text { مشكلة من مشكلات البحث؛ حيث إنه يعتمد } \\
& \text { ب- قائمــــة منطلبـــات التربيـــة المهنيـــة }
\end{aligned}
$$

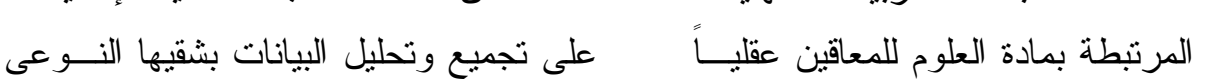

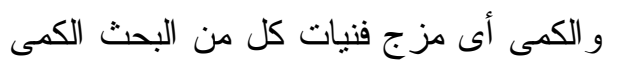

$$
\begin{aligned}
& \text { (إعداد الباحثنة) } \\
& \text { و الكيفى مما يساعد على وضــــوح البيانــات }
\end{aligned}
$$

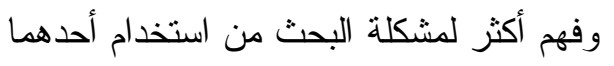

$$
\begin{aligned}
& \text { بمفرده، وتمنلت الخطوات كالتالى: }
\end{aligned}
$$

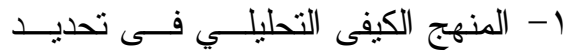

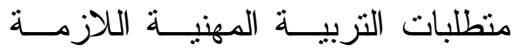

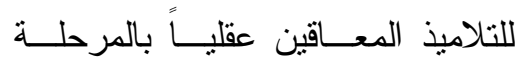

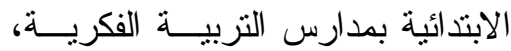

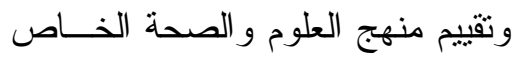

$$
\begin{aligned}
& \text { بهק. } \\
& \text { r- المنهج التجريبي( الكمى) القائم على } \\
& \text { التصميم القبلي - البعدي لمجمو عنين } \\
& \text { ، حيث ينم تدريس بعض الوحــدات }
\end{aligned}
$$

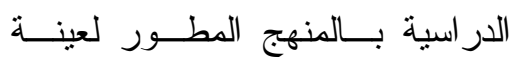

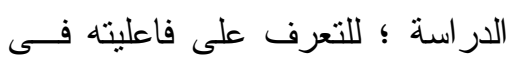

$$
\begin{aligned}
& \text { تتمية التحصيل و المهـــار ات العمليــة }
\end{aligned}
$$

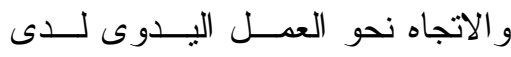

$$
\begin{aligned}
& \text { التلاميذ المعاقين عقلياً. } \\
& \text { ع- أداة تحليل محتــوى مــنهج العلــوم } \\
& \text { للمعاقين عقلياً. (إعداد الباحثة) } \\
& \text { 0- اختبار تحــصبلى مـصور • (اعـداد } \\
& \text { (الباحثة) } \\
& \text { 7- بطاقة ملاحظــــة المهـــار ات العمليــة } \\
& \text { (إعداد الباحثة) (لماحة) } \\
& \text { - V مقياس الاتجاه نحو العهــل اليـدوى } \\
& \text { (إعداد الباحثة) } \\
& \text { م كتاب التلميذ (إعداد الباحثة) } \\
& \text { منهج البحث: }
\end{aligned}
$$




\section{تصميم البحث :}

يمكن تمثيل البحث المختلط فى المخطط التالى شكل(1) التصميم الاستكثافى:

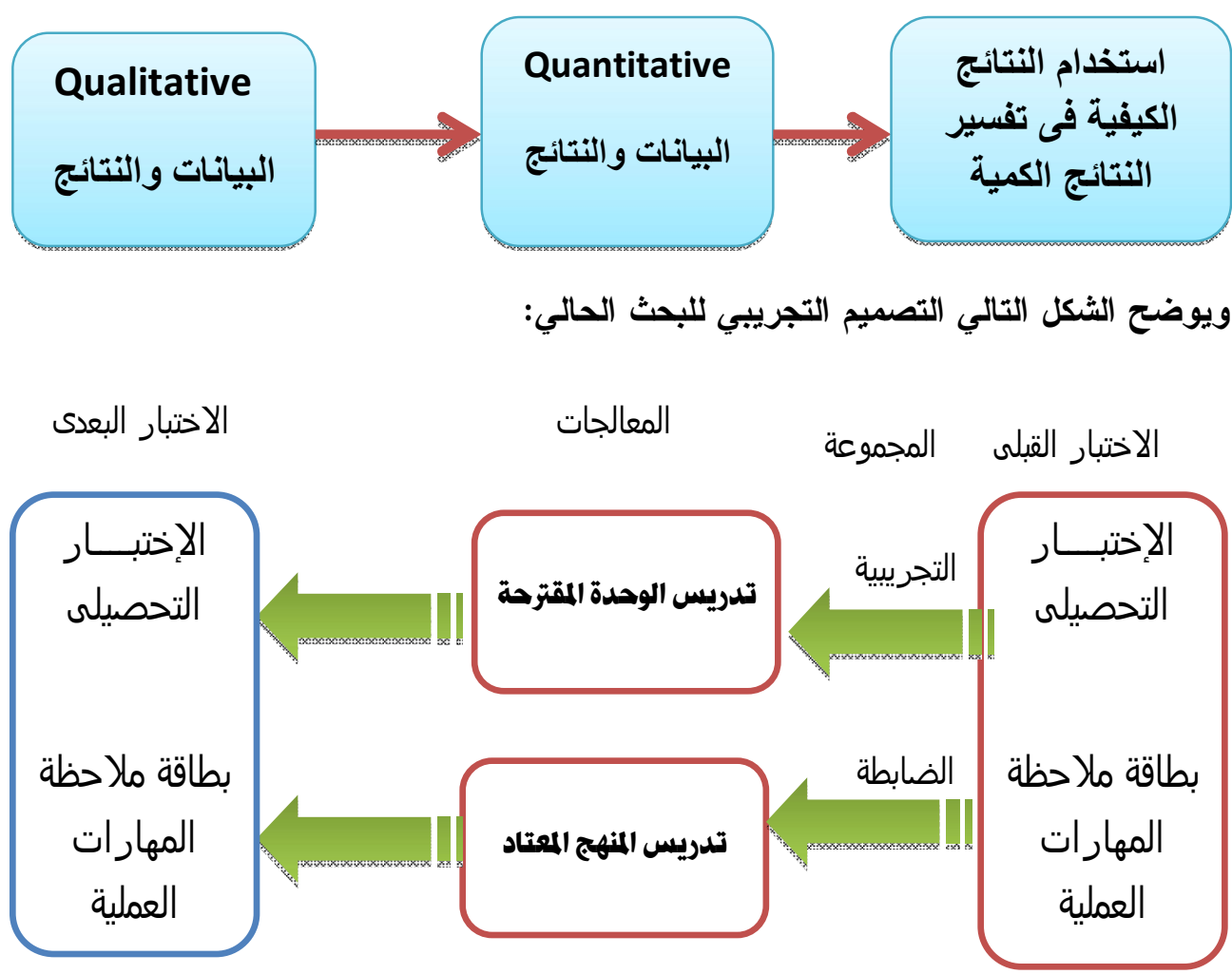

$$
\text { شكل (ץ): التصميم التجريبي للبحث }
$$

تحديد مصطلحات البحث:

تحقيق أهداف النظام التعليمي(جودت سعادة،

$$
\text { .(rq r. r...) }
$$

Curriculum

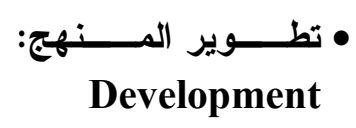

ويعرف إجرائياً بأنه عمليــة إدخــال

ويُعرف على أنـــه التغييــر الكيفـي

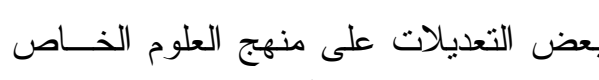

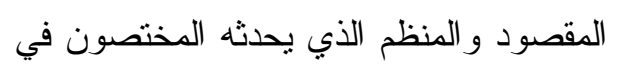

بالتلاميذ المعاقين عقلياً بالمرحلة الابتدائيــة،

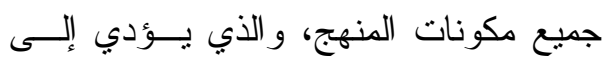

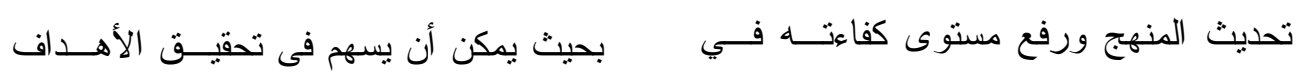


• المعـــاقون عقليــاً القـــابلون للـــتملم:

Educable Mentally Retarded

ويعرفها بنو I Benoit بأنها حالة مسن

النقص في وظائف العقــل نتيجـــه عوامــلـل

متعددة، تؤدي إلى ضعف فــي فــي كفــاءها

الجهاز العصبي، ونقص القدرة العامة علــى لـى لــي

النمو ، و القدرة على التكيف. ( على مسافر، لعنى

(1. 6r. Th

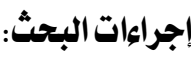

1 - تحديـــــ متطلبــات التربيـــة المهنيــــة المرتبطة بمناهج العلوم من وجهة نظر

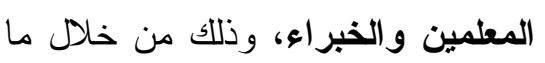

يلي:

- دراسة خصائص وحاجــات التلاميــذ

المعاقين عقلياً بالمرحلة الابتدائية مسنـ درحن

خلد الأدبيات التزبوية، بالإضافة إلى بلى الابلى

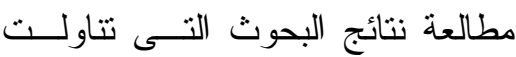

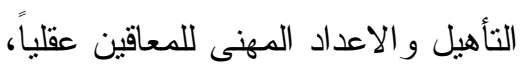

$$
\text { وتدريس العلوم لها. }
$$

- مر اجعة أهداف تعليم المعاقين عقليــاً،

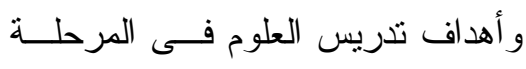

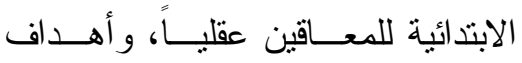

التأهيل المهنى للمعاقين عقلياً.

- مر اجعة البر امج، و المشرو عات العربية

و العالمية المعدة للعـادين و المعـاقين

عقلياً.

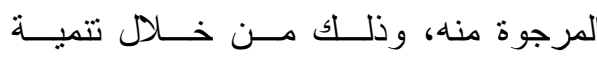
المهار ات العملية لديهم.

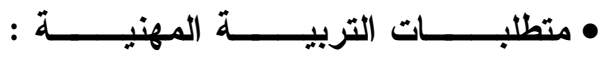

Professional

Education

Requirements

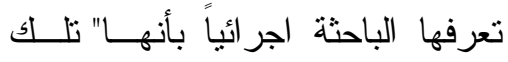

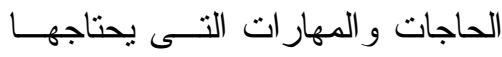

المعاق عقليا لينمو نمواً مهنياً صحيحاً

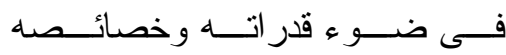

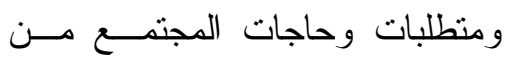

حوله، ليحصل علــى مهزنــة معينــــة

$$
\text { ويدخل سوق العمل". }
$$

• المهار ات العملية:practical skills

يعرفها عايش زيتون بأنهـا (0. . . Y.

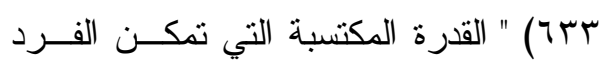

المتعلم من إنجاز ما توكل إليه مــن أعمـــال

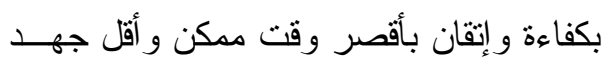

$$
\text { وعائد أوفر" }
$$

وتعرفها الباحثة اجرائيا بأنهـــا" أنهـــا

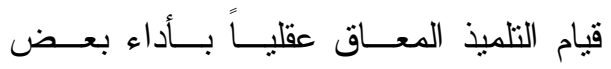

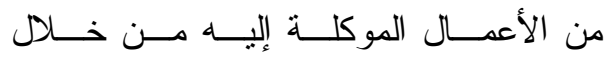

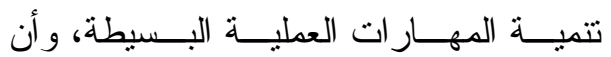

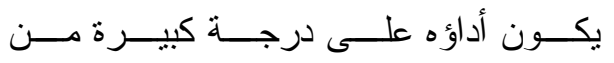

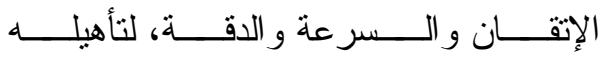

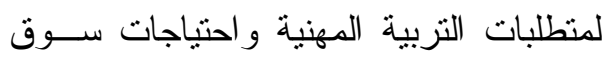

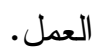


- عمل مقابلات مع أولياء الأمور لتحديد المتطلبات المهنية اللازمـــة لأبنــائهم فى المستقبل للــدخول فــى مرحلــــة

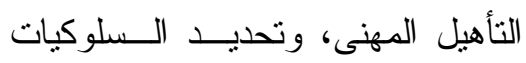
و المهار ات التى ينبخى نو افرها مع هذه ونه

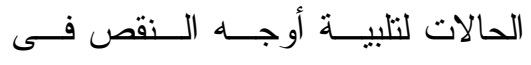
المعرفة والثقة بالذات وامكانية اختيار

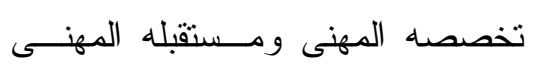
بار ادته دون تدخل أو سبطرة من أحد عليهم.

ץ- عرض قائمة منطلبات التزبية المهنيــة

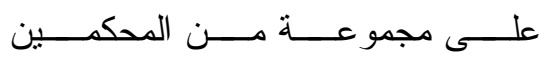
المتخصصين فى المناهج وطرق تدريس الفئــات الخاصــــة بكليـــات التزبيــــة، وموجهي ومعلمــي العلــوم بمــدارس التربية الفكرية

r- وضع قائمة بمنطلبات التزبية المهنية فى

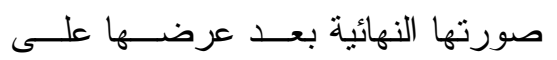

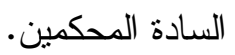

ع - استخدام قائمة منطلبات الثربية المهنيـــة

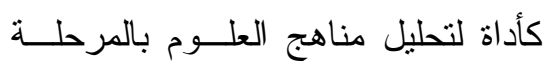
الابندائية بمدارس التربية الفكرية.

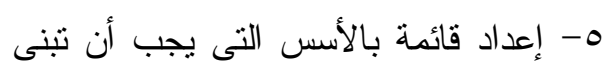

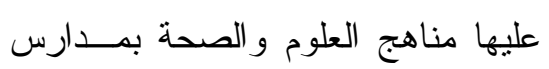

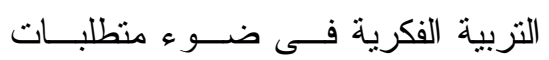
التزبية المهنية.
- الاطلاع على الأدبيــات و الدر اســات السابقة التي اهتمت بالتأهيل و الاعـــداد الادي المهنى . - مر اجعة وفحص البر امج العلمية التـي

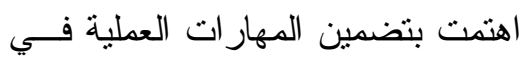

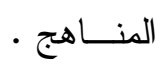

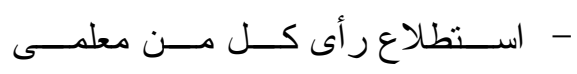

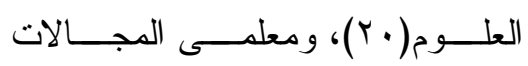

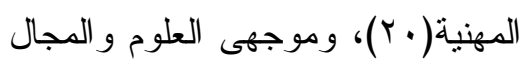

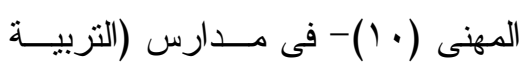

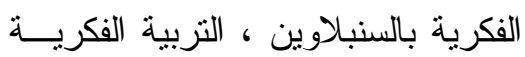
بالمنصورة، و التربية الفكرية بـسنفا،

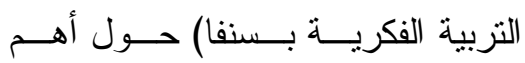
المجالات و المتطلبات المهنية المرتبطة

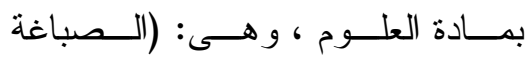

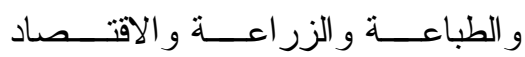

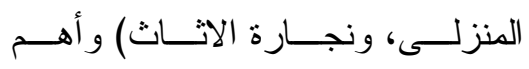

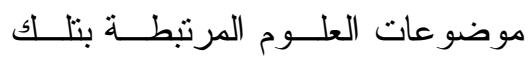
المجالات و التى تلبى متطلبات التزبيــة المهنية للمعاقين عقلياً. - مر اجعــة وتحليــل بعـضـ الأعمــال

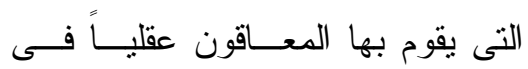

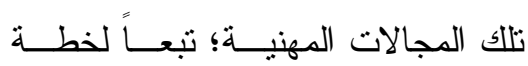

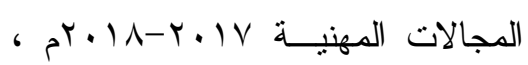
وتحديد موضو عات العلــوم المناســبة لأدائها.. 
• 1-بناء أدوات البحث التجريبية و المتمتلـــة

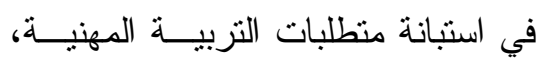
والاختبار التحصيلي، مقياس المهارات

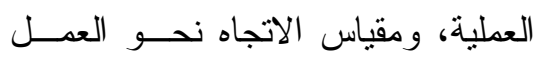
اليدوى. - (اليد.

1ا-عرض أدوات البحث التجريبيــة علـى

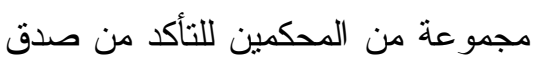

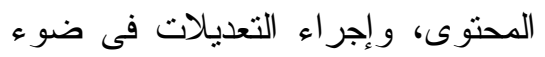
آر اء المحكمين.

rا-التطبيق الاســنطلاعي لأدوات البحــث

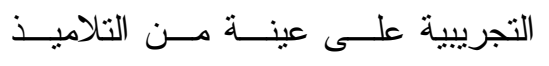
المعاقين عقلياً؛ لحساب ثباتها.

با-وضع أدوات البحــث فــى صــورتها النهائية.

ع ا-تحديد العينة الأساسـية للبحــث مـنـ

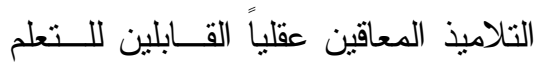
حيث نم تطبيق اختبار ذكاء ســتانفورد

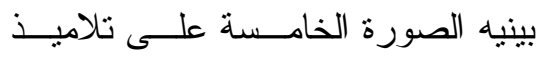
الصف الخامس الابتدائي حيث تزاوحت

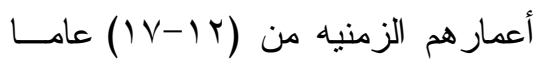

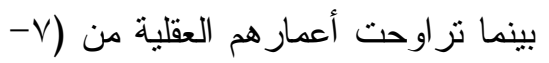

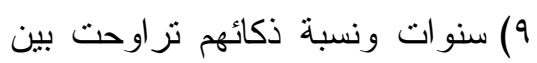
.$(79-00)$

10-تطبيق أدوات البحث التجريبية علـى عينة البحث قبلياً. 7 ا-تدريس الوحدة المحددة لعينة الدراسة.
1- نطوير منهج العلوم والصحة بمــدارس

التربية الفكرية فى ضوء قائمة الأسـس لهـ كما يلي:

• تحديـــد الأهـــداف العامــة للمــنهج

$$
\text { المطور • }
$$

• تحديد الإطار العام لمحتوى المــنهج

المطور •

• تحديد طرق التـدريس والأنـشطة و المو اد التعليمية اللازمة لتـدريس المنهج المطور . تحديد أساليب تقويم المنهج المطور . V- بناء كتاب التلميذ لفصل در اسي كامــل

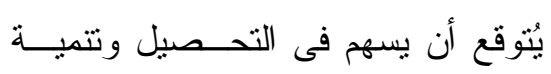

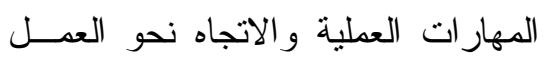

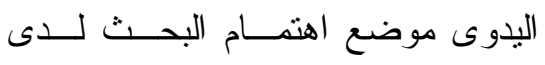
التناميذ المعاقين عقلياً.

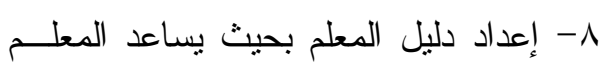

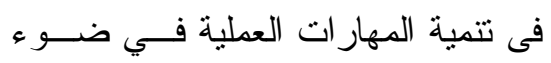
متطلبات التزبية المهنية موضع اهتمــام الدر اسة لاى التلاميذ المعاقين عقلياً.

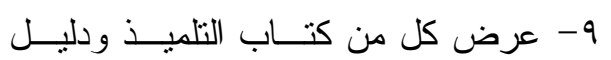
المعلم على مجموعـــة مــن المحكمــين المتخصصين فى المناهج وطرق تدريس

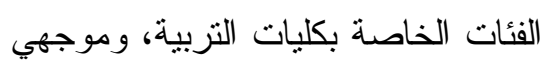

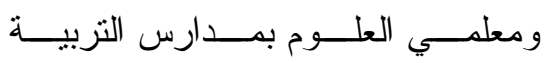

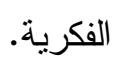


جاءت جميع قيم (U) أقل من القيمة الجدولية

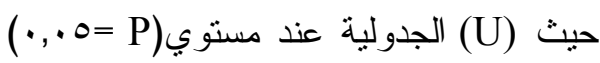

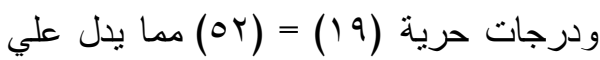
تفوق المجموعة التجريبية علي المجموعــة الضابطة في الاختبار التحصيلى، مما يــل لهل

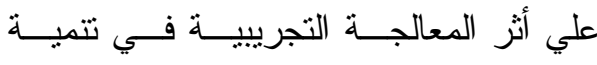
التحصيل .

ويمكن تفسير تلك النتيجة التى أسفرت عنها فعالية الوحدة المطــورة- المتمثلـــة فــى المنهج المطور - في:

تتمية التحصيل لدى عينـــة الدراســـة

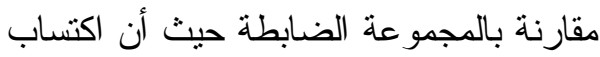
المهار ات العملية و الخبر ات العملية و الحياتية فى الموضوعات المتعلقــة بـــــهج العلــوم المطور ساهمت فى تتمية التحصيل بصورة بهرة جيدة وبشكل أفضل. r-اختبار الفرض الثاني: ينص الفرض الثاني فى البحث علـى

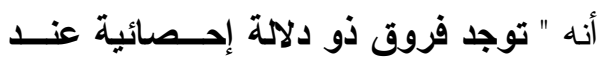

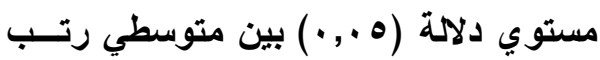

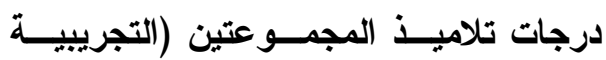
والضابطة) في التطبيــق البعــــي لبطاقــة ملاحظة المهارات العملية لصالح المجموعة التجريبية ".

استخدمت الباحثة معادلة (مان ويتتي)

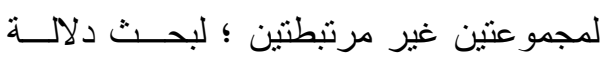

IV الدر اسة بعدياً.

11-معالجة البيانات باســتخدام الأســاليب

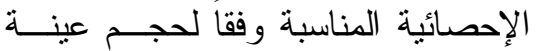
البحث، وطبيعة المتغير ات. 9 1-مناقثة النتائج و تفسير ها. • ץ-ثقديم التوصيات و المقترحات فى ضوء.

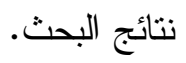

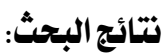
1-اختبار الفرض الاول:

ينص الفرض الاول فى البحث علــى

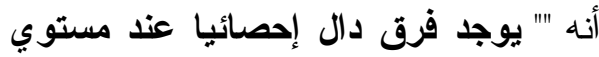
دلالة (ه., •) بين متوسطي رتب درجـات تلاميذ المجموعتين (التجريبية والــضابطة)

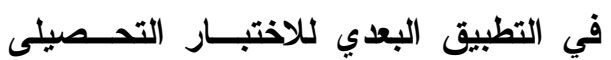

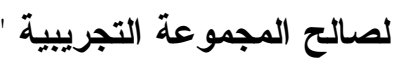

استخدمت الباحثة معادلة (مان ويتتي)

لهجموعتين غبر مرتبطنتين؛ لبحـث دلالـــة الفروق بين متوسطي رتب درجات كل مـنـ

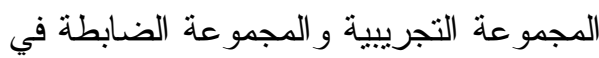
مستويات الاختبار التحصيلى، و الدرجة الكلية

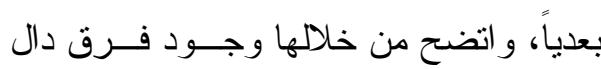

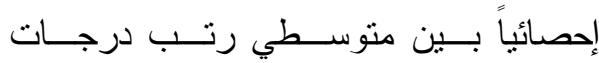

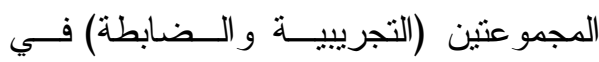

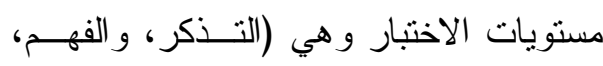

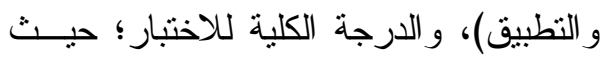


الضابطة في أبعاد مقياس الاتجاه نحو العمل اليدوى، والدرجة الكلية بعدياً.

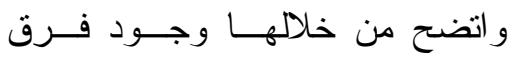

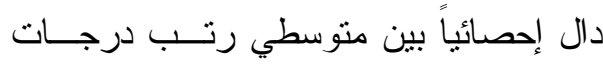

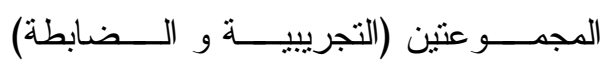
في مقياس الاتجاه، والدرجة الكلية للمقياس؛

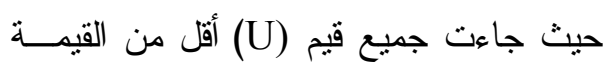

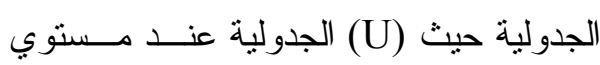

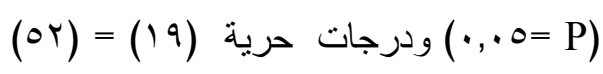
مما يدل علي تفوق المجموعة التجريبية علي

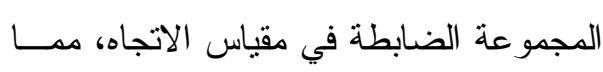

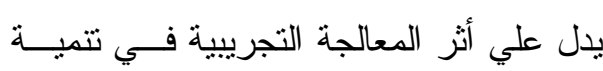
الاتجاه نحو العمل اليدوى . لئ لئه

وفي ضوء تلك النتيجة، يمكن قبول الفرض الخامس من فروض البحث وهو: ويمكن تفسير تلك النتيجة التــي أســفرت

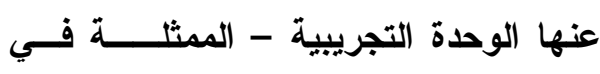

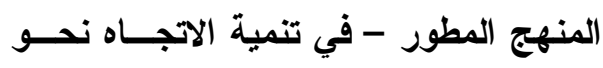

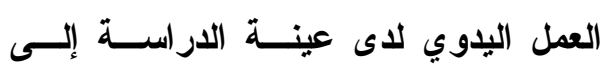
ما يلي : التعل :

• اثتر الك التاميذ مع الباحثة فـى رسـم تتفيذ واعداد الأدوات المستخدمة قد أناح

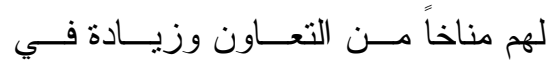

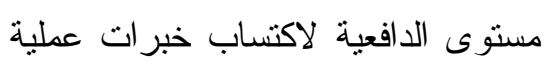
متجددة، مما ساهم في تحسين اتجــاههم

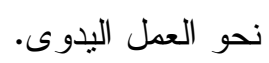

الفروق بين منوسطي رتب درجات كل مـن المجموعة التجريبية و المجموعة الــضـابطة

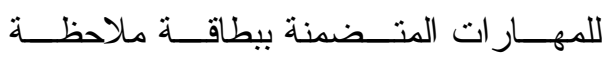
المهار ات العملية ، و الدرجة الكلية و اتــضه من خلالها وجود فرق دال إحـصائياً بـين

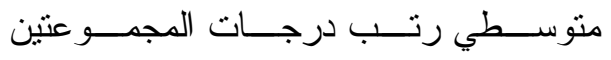
(التجريبية و الضابطة) في مهار ات بطاقــة

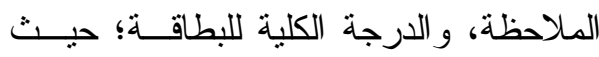
جاءت جميع قيم (U) أقل من القيمة الجدولية حيث (U) الجدولية عند مستوي( P = ه ., •)

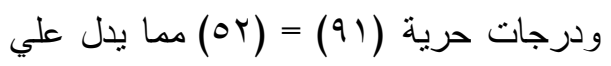
تفوق المجموعة التجريبية علي المجموعــة

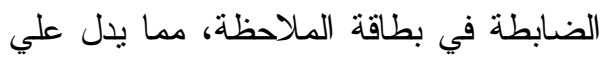
أثز المعالجة التجريبية في تتمية المهــارات العملية . r-اختبار الفرض الثالث: ينص الفرض الثالث فى البحث عانـى في

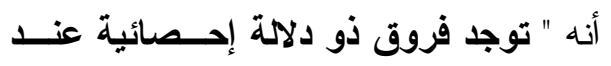

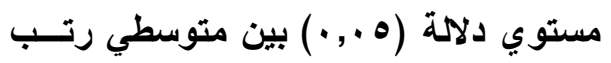

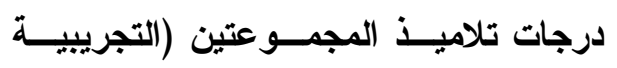
والضابطة) في التطبيق البعـــي لمقيــاس الاتجاه نحو العمل اليدوى لصالح المجموعة التجريبية ". استخدمت الباحثــة معادلــة (مــان ويتتي) لمجموعتين غير مرتبطتين ؛ لبحــث دلالة الفروق بين متوسطي رثب درجات كل

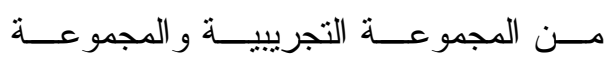




\section{تعليق عام على النتائج:}

باستعراض نتائج البحث - فى حدود العينة وأدوات البحث، ووحدة التجريب، ومتغيرات البحث - يمكن الإشارة إلى وودات

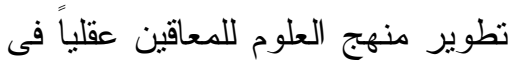

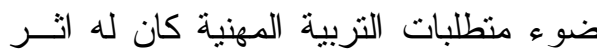
بالغ في تتمية بعض المهار ات العملية للمعاق

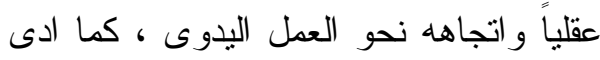
إلى تحسين مهار اته اليدوية وخبر اته العملية، وتحسين مهار اته الادائية، وتحسين اســتـعداد

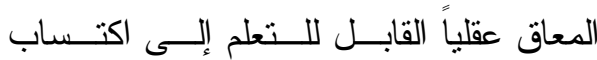

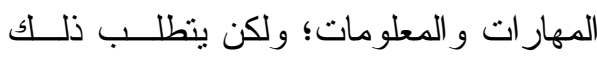

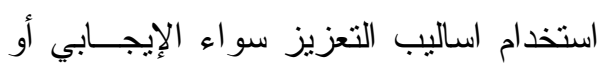
السلبى وكان له بالغ الأثر حيث كانت نواتج التعلم لكل مهارة و التى قام بـه التلاميذ بمثابة

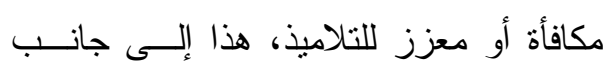

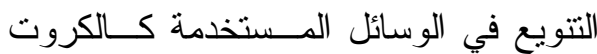
المصورة و الفيديو و استخدام أدوات النـشاط لزيادة دافعية التلاميذ و استعدادهم للتعلم، وقد ولفئ ظهر ذلك جلياً فى وجود فروق بين درجات

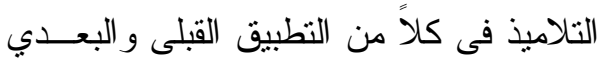
لبطاقة ملاحظة المهار ات العملية و الاختبـــار التحصيلى ومقياس الاتجاه نحو العمل اليدوي للمجموعـــة التجريبيـــة، و الفـــروق بــــين المجموعتين التجريبية و الضابطة فى التطبيق البعدي للاختبار التحصيلى ومقياس الاتجاه، وبطاقة ملاحظة المهار ات العملية.
• تمكن تلاميذ المجموعة التجرييـــة مــن تحليل المهمة قد ساعدهم علــى تــدعيم

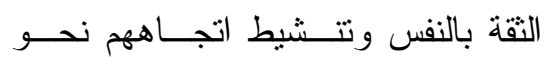

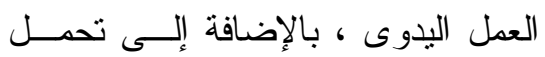

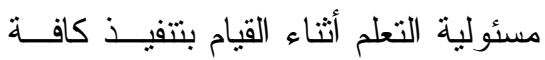
الأنشطة.

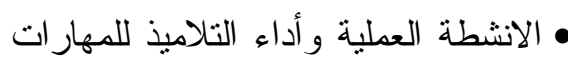
عملية ؛ أدى إلى إثارة انتباههم، وبالتالي ولئ

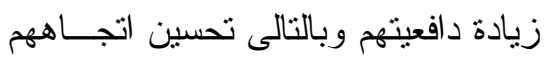

$$
\text { ع -اختبار الفرض الر ابع: }
$$

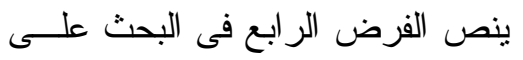

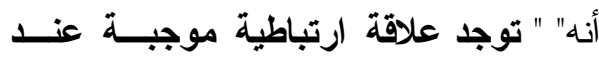

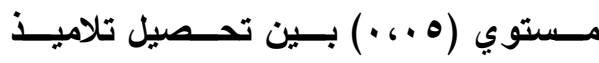
المجموعة التجريبية، وامتلاكهم للمهـارات العملية، واتجاههم نحو العمل اليدوى ". استخدمت الباحثة معادلــة ســبيرمان

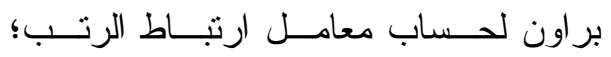

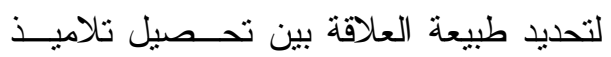

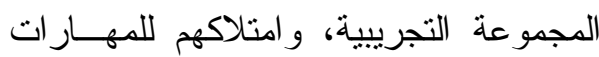

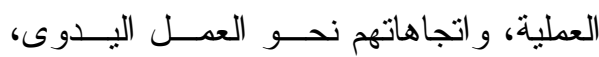
و اتضح من خلالها و وجود علاقة ارتباطيــة

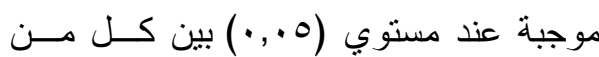

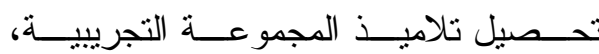

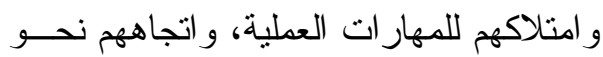

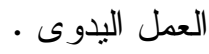


الدراسات العليا، جامعة نايف العربيـــة

$$
\text { للعلوم الأمنية. }
$$

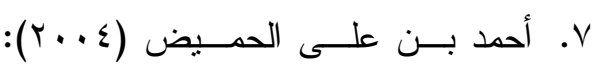

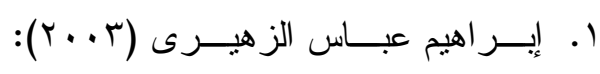

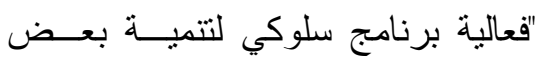

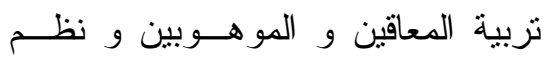

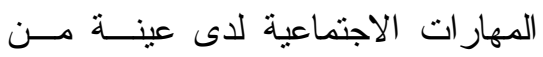

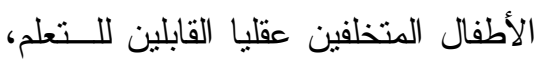

رسالة ماجستير غير منـشورة، كليــة

الدراسات العليا، جامعة نايف العربيــة

$$
\text { للعلوم الأمنية. }
$$

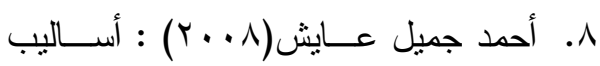

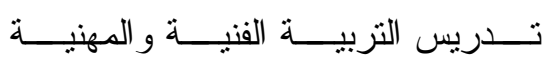

تعليمهم: إطار فلسفي وخبر ات عالميــة، وندة

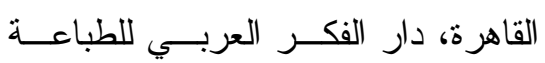

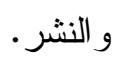

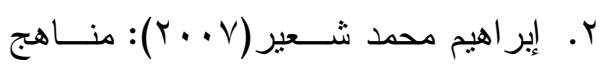

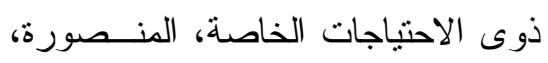

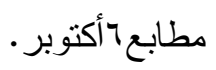

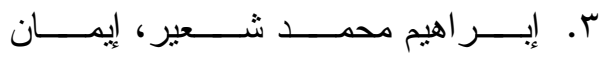

و الرياضية، عمان، دار المسيرة للطباعة

$$
\text { و والنشر. }
$$

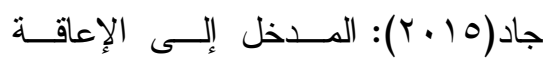
العقلية، المنصورة، مكنبة الإيمان.

9. أحمد عبد اللطيف وحيد (1 . . r): علــ

النفس الاجتماعي، عمان، دار المسسيرة

$$
\text { للنشر و التوزيع. }
$$

ـ. الاتحاد النوعى لهيئات رعايــة الفئــات

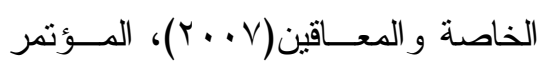
العربى السادس، القاهرة

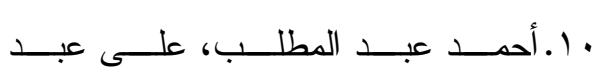
المطلب(10 ب ب): فاعلية برنــامج قـائم 0. أحمد النجدى، على راشد، منــى عبــد

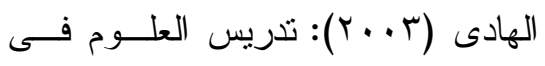
على الأنشطة غير الصفية فــى تتميــة بعــ المهـــار ات اللغويــــة للأطفــال

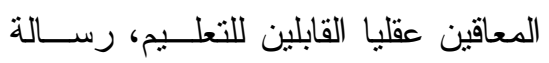

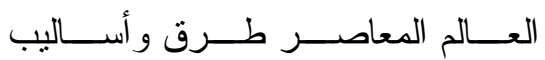
و استر اتيجيات حديثة فى تدريس العلوم، القاهرة، دار الفكر العربى. ماجستير غير منشورة، معهد الدراسات التربوية، جامعة القاهرة.

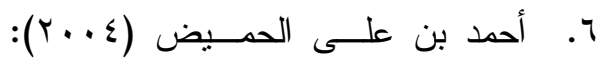

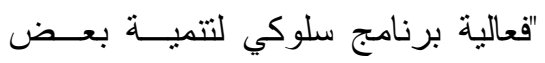

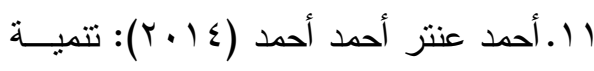

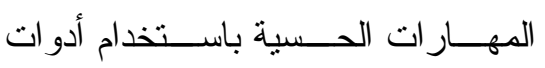

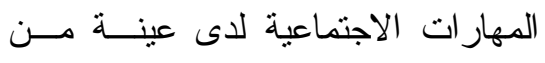

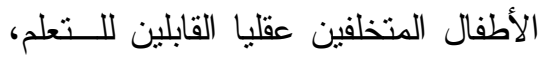
منتسوري و اثره فـــي تحــين الانتبــاه رسالة ماجستير غير منـشورة، كلبــة 
لذوي الحاجات الخاصة، طء، عدــان،

$$
\text { الأردن، دار الفكر . }
$$

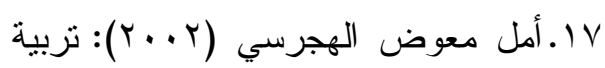

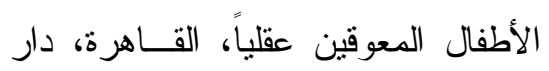

$$
\text { الفكر العربي. }
$$

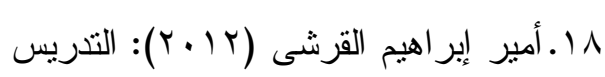
لذوى الاحتياجات الخاصة بين التصميم و التتفيذ، القاهرة، عالم الكتب.

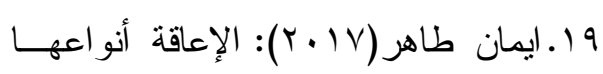
وطرق التغلب عليها، وكالة الــصحافة

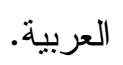

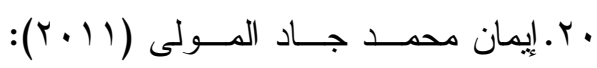
تطوير منهج العلوم لتتمية بعض أبعساد التقافة العلمية لاى التلاميــــ المعـاقين عقليا بالمرحلة الابتدائية، رسالة دكتور اه

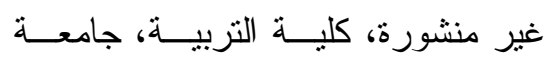
المنصورة.

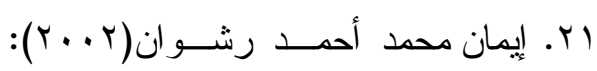

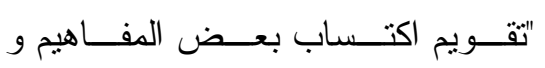

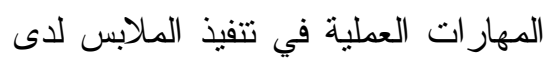
تلميذات الصف الثالث الاعدادي المهني بمدارس الامل للصم و ضعاف السمع"،

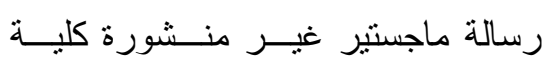
التربية، جامعة جنوب الو ادى.

Y.M.باسم محمد ولي، ومحمد جاسم محمـــ

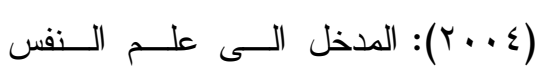

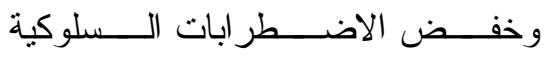
لدى الأطفــال ذوبي الإعاقـــة العقليـــة

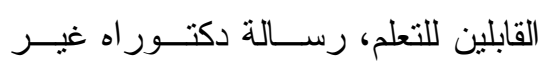

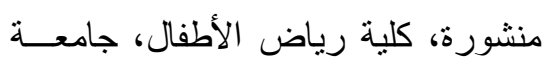

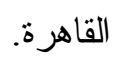
r أحمد عو اد، ومجدى الثحات (ع . . r):

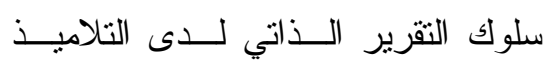
العاديين عقلياً وذوى صــعوبات الــتعلم و القابلين للتعلم ، المؤتمر العلمي الثـانى ودئ

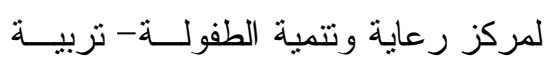
ذوى الاحتياجات الخاصة فــى الــوطن العربي - الواقع و المسنقبل، كلية التربية

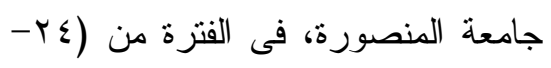

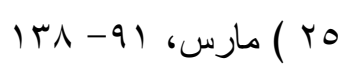

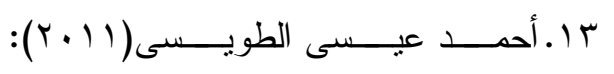

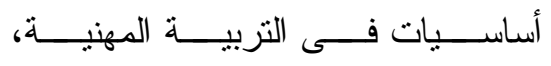

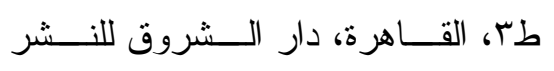
و التوزيع.

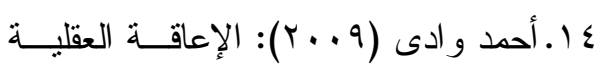
"أسباب - نتخيص - تأهيل"، عمــان، دار أسامة للنشر .

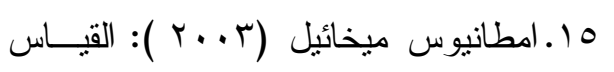
و التقويم في التربية، دمشق، منسشئشورات جامعة دمشق.

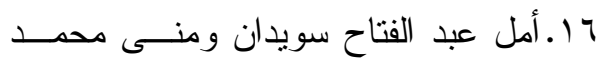

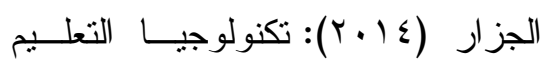




$$
\begin{aligned}
& \text { وتخطيطهــــــا وتطوير هـــــا، طا كدار } \\
& \text { الثروق، عمان. }
\end{aligned}
$$

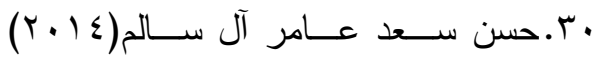

$$
\begin{aligned}
& \text { التخلف العقلي(حقائق علميــة وبــــر امج }
\end{aligned}
$$

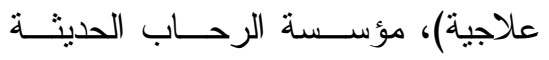

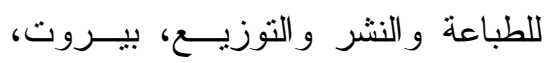

$$
\begin{aligned}
& \text { لبنان }
\end{aligned}
$$

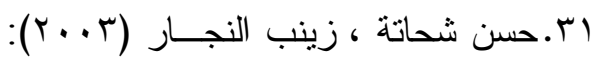

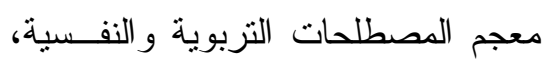

$$
\begin{aligned}
& \text { القاهرة، الدار المصرية اللبنانية }
\end{aligned}
$$

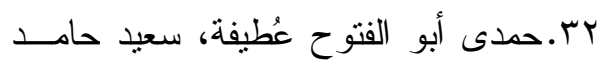

$$
\begin{aligned}
& \text { (1990): النشاط العلىــى فـى حئى حيـاة } \\
& \text { أبنائنا، القاهرة ، دار سفير • }
\end{aligned}
$$

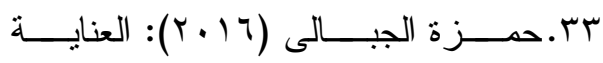

$$
\begin{aligned}
& \text { بالأطفال المعاقين تعليمياً، القــاهرة، دار }
\end{aligned}
$$

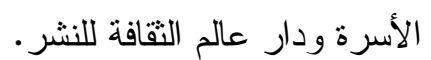

\section{ثانيا : المراجع الأجنبية}

29.American Association on Intellectual and Developmental Disabilities

http://www.aamr.org/polies/fag mentalretardation.3/6/2006.(20

06).AAID

30.Bender, M\&dt al(1996),A

Functional Curriculum for

Teaching Students with

$$
\begin{aligned}
& \text { الاجتماعي، عمان، الاردن، دار التقافــة } \\
& \text { للنشر و التوزيع. } \\
& \text { r r.تغريد عمران ورجاء الثناوي، وعفاف }
\end{aligned}
$$

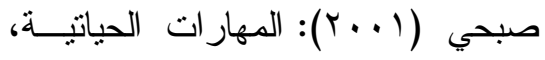

$$
\begin{aligned}
& \text { القاهرة، مكتبة زهر اء الثرق. }
\end{aligned}
$$

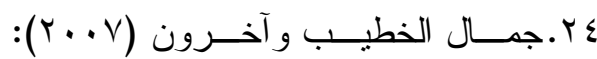

$$
\begin{aligned}
& \text { مقدمة فى تعليم الطلبة ذوى الاحتياجات }
\end{aligned}
$$

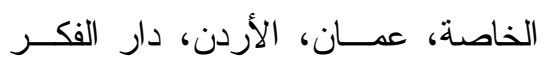

$$
\begin{aligned}
& \text { للنشر و التوزيع. }
\end{aligned}
$$

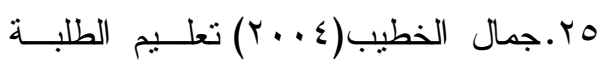

$$
\begin{aligned}
& \text { ذوب الحاجات الخاصة فــي المدرســة }
\end{aligned}
$$

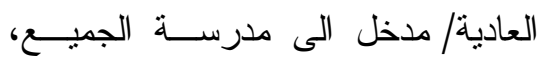

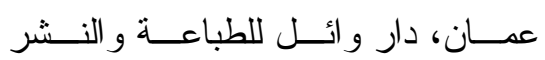

$$
\begin{aligned}
& \text { و التوزيع. }
\end{aligned}
$$

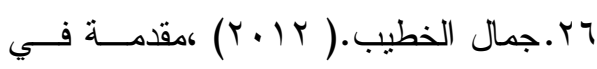

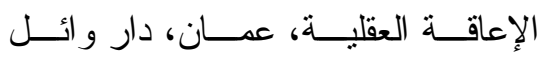

$$
\begin{aligned}
& \text { للنشر. }
\end{aligned}
$$

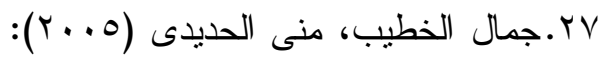
المدخل إلى التربية الخاصة، عمان، دار حنين.

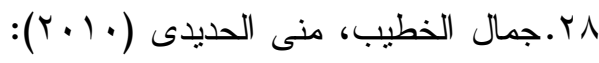

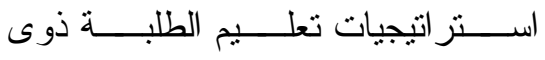

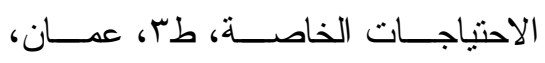
الاردن، دار الفكر العربى.

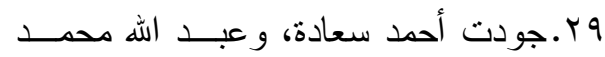

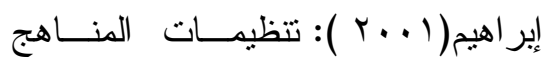




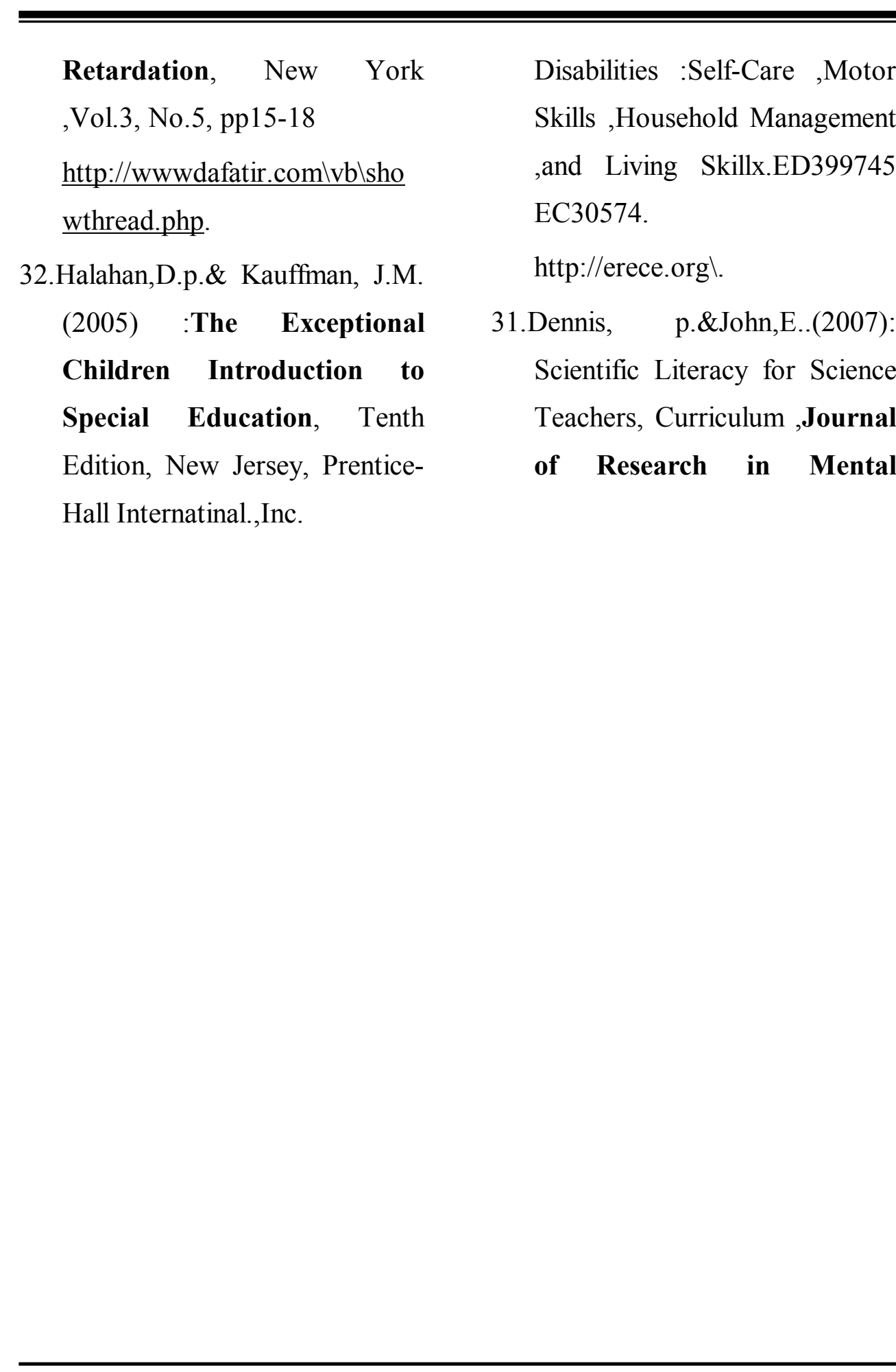

